\title{
Long-term and serious harms of medical cannabis and cannabinoids for chronic pain: A
}

\section{systematic review of non-randomized studies}

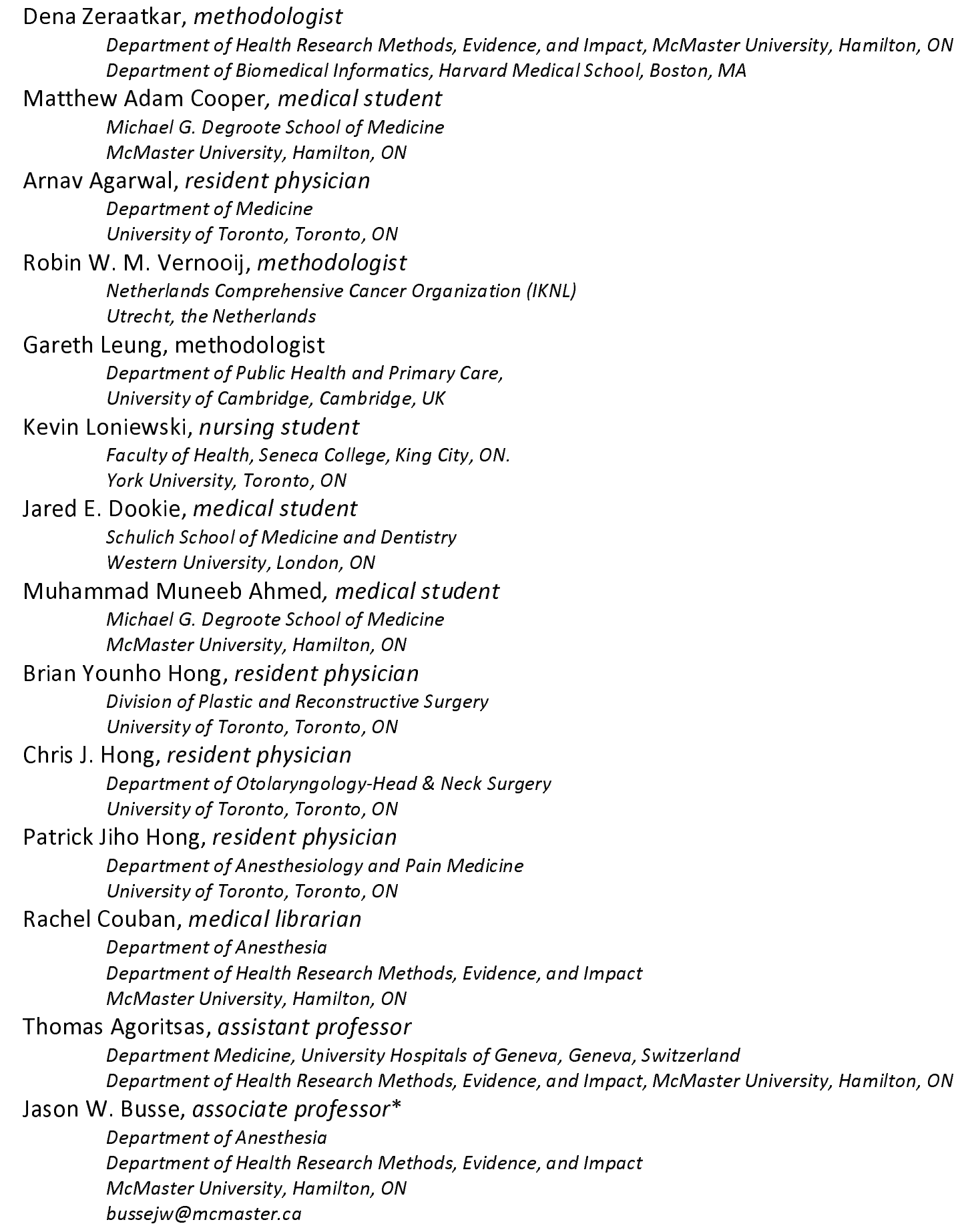


medRxiv preprint doi: https://doi.org/10.1101/2021.05.27.21257921; this version posted May 29, 2021. The copyright holder for this preprint (which was not certified by peer review) is the author/funder, who has granted medRxiv a license to display the preprint in perpetuity.

*Corresponding author

51 Running head: Harms of medical cannabis

52 Abbreviations: Cochrane Central Register of Controlled Trials (CENTRAL), Palmitoylethanolamide (PEA),

53 tetrahydrocannabinol (THC)

54 Keywords: Medical cannabis, chronic pain, adverse events, harms, non-randomized studies,

55 observational studies

56 Disclaimers: None.

57 Funding: DZ is supported by a Banting Postdoctoral Fellowship.

58 Ethics approval: The systematic review is exempt from ethics approval.

59 Data: Data will be made available upon publication: https://osf.io/ut36z/

60 Acknowledgements: We thank the members of the Rapid Recommendations panel for critical feedback

61 on the selection of the adverse events of interest. We thank James Mackillop, PhD, for his help with the

62 interpretation of problematic cannabis use, abuse, dependance and withdrawal syndrome within

63 studies.

64 Authors' Contributions: JWB and TA conceived the idea. RC designed and conducted the search. DZ, $65 \mathrm{MAC}, \mathrm{AA}, \mathrm{GL}, \mathrm{KL}, \mathrm{JD}, \mathrm{BYH}, \mathrm{CH}$, and PJH screened search records, extracted data, and assessed the risk of 66 bias of the eligible studies. DZ conducted analyses. DZ, JWB, and TA interpreted the data. DZ wrote the 67 first draft of the manuscript. JWB and TA critically revised the manuscript. All authors reviewed and 68 approved the final version. DZ and JWB are the guarantors.

69

$70 *$ I, the Submitting Author, have the right to grant and does grant on behalf of all authors of the Work

71 (as defined in the author licence), an exclusive licence and/or a non-exclusive licence for contributions

72 from authors who are: i) UK Crown employees; ii) where BMJ has agreed a CC-BY licence shall apply,

73 and/or iii) in accordance with the terms applicable for US Federal Government officers or employees

74 acting as part of their official duties; on a worldwide, perpetual, irrevocable, royalty-free basis to BMJ

75 Publishing Group Ltd ("BMJ") its licensees.

76

77 Word count: 5,170 
medRxiv preprint doi: https://doi.org/10.1101/2021.05.27.21257921; this version posted May 29, 2021. The copyright holder for this preprint (which was not certified by peer review) is the author/funder, who has granted medRxiv a license to display the preprint in perpetuity. It is made available under a CC-BY-NC-ND 4.0 International license .

\section{Abstract}

Objective: To establish the risk and prevalence of long-term and serious harms of medical cannabis and cannabinoids for chronic pain.

Design: Systematic review and meta-analysis.

Data sources: MEDLINE, EMBASE, PsycInfo, and the Cochrane Central Register of Controlled Trials (CENTRAL) from inception to April 1, 2020.

Study selection: Non-randomized studies reporting on harms of medical cannabis or cannabinoids in people living with chronic pain with $\geq 4$ weeks of follow-up.

Data extraction and synthesis: A parallel guideline panel provided input on the design and interpretation of the systematic review, including selection of adverse events for consideration. Two reviewers, working independently and in duplicate, screened the search results, extracted data, and assessed risk of bias. We used random-effects models for all meta-analyses and the GRADE approach to evaluate the certainty of evidence.

Results: We identified 39 eligible studies that enrolled 12,143 patients with chronic pain. Very low certainty evidence suggests that adverse events are common (prevalence: $26.0 \%$; $95 \% \mathrm{Cl} 13.2$ to 41.2 ) among users of medical cannabis or cannabinoids for chronic pain, particularly any psychiatric adverse events (prevalence: 13.5\%; 95\% Cl 2.6 to 30.6). However, very low certainty evidence indicates serious adverse events, adverse events leading to discontinuation, cognitive adverse events, accidents and injuries, and dependence and withdrawal syndrome are uncommon and typically occur in fewer than one in 20 patients. We compared studies with $<24$ weeks and $\geq 24$ weeks cannabis use and found more adverse events reported among studies with longer follow-up (test of interaction $p<0.01$ ). Palmitoylethanolamide was usually associated with few to no adverse events. We found insufficient evidence addressing the harms of medical cannabis compared to other pain management options, such as opioids.

Conclusions: There is very low certainty evidence that adverse events are common among people living with chronic pain who use medical cannabis or cannabinoids, but that few patients experience serious adverse events. Future research should compare long-term and serious harms of medical cannabis with other management options for chronic pain, including opioids. 
medRxiv preprint doi: https://doi.org/10.1101/2021.05.27.21257921; this version posted May 29, 2021. The copyright holder for this preprint (which was not certified by peer review) is the author/funder, who has granted medRxiv a license to display the preprint in perpetuity.

It is made available under a CC-BY-NC-ND 4.0 International license. 
medRxiv preprint doi: https://doi.org/10.1101/2021.05.27.21257921; this version posted May 29, 2021. The copyright holder for this preprint

(which was not certified by peer review) is the author/funder, who has granted medRxiv a license to display the preprint in perpetuity.

It is made available under a CC-BY-NC-ND 4.0 International license .

107 What is already known on this topic

108

109

110

111

112

113

114

115

116

117

118

119

120

- Medical cannabis and cannabinoids are increasingly used for the management of chronic pain.

- Clinicians and patients considering medical cannabis or cannabinoids as a treatment option for chronic pain require evidence on benefits and harms, including long-term and serious adverse events to make informed decisions.

\section{What this study adds}

- Very low certainty evidence suggests that adverse events are common among people living with chronic pain who use medical cannabis or cannabinoids, including psychiatric adverse events, though serious adverse events, adverse events leading to discontinuation, cognitive adverse events, accidents and injuries, and dependence and withdrawal syndrome are uncommon.

- There is insufficient evidence comparing the harms of medical cannabis or cannabinoids to other pain management options, such as opioids. 
medRxiv preprint doi: https://doi.org/10.1101/2021.05.27.21257921; this version posted May 29, 2021. The copyright holder for this preprint (which was not certified by peer review) is the author/funder, who has granted medRxiv a license to display the preprint in perpetuity. It is made available under a CC-BY-NC-ND 4.0 International license .

\section{Background}

Chronic pain is the primary cause of health care resource use and disability among working adults in North America and Western Europe. ${ }^{12}$ The use of cannabis for the management of chronic pain is becoming increasingly common due to pressure to reduce opioid use, increased availability and changing legislation, shift in public attitudes and decreased stigma, and aggressive marketing. ${ }^{34}$ The two most-studied cannabinoids in medical cannabis are delta-9-tetrahydrocannabinol (THC) and cannabidiol (CBD). ${ }^{5}$ THC binds to cannabinoid receptors type 1 and 2 , is an analog to the endogenous cannabinoid, anandamide, and has shown psychoactive, analgesic, anti-inflammatory, antioxidant, antipruritic, antispasmodic, and muscle-relaxant activities. CBD directly interacts with various ion channels to produce analgesic, anti-inflammatory, anti-convulsant and anxiolytic activities, without the psychoactive effect of THC. $^{5}$ Use of cannabis for therapeutic purposes, however, remains contentious due to its known and suspected harms. ${ }^{6-9}$

Though common adverse events caused by medical cannabis, including nausea, vomiting, headache, drowsiness, and dizziness, have been well documented in randomized controlled trials and reviews of randomized controlled trials, ${ }^{10}{ }^{11}$ less is known about potentially uncommon but serious adverse events, particularly events that may occur with longer durations of medical cannabis use, such as dependence, withdrawal symptoms, and psychosis. ${ }^{42-17}$ Such adverse events are usually observed in large nonrandomized studies that recruit larger numbers of patients and typically follow them for longer durations of time. Further, evidence from non-randomized studies may be more generalizable, since randomized controlled trials typically use strict eligibility criteria.

The objective of this systematic review and meta-analysis is to summarize the evidence on the risks and, when evidence on risk is not available, the prevalence of adverse events related to medical cannabis and cannabinoids from non-randomized studies. This evidence synthesis is part of the BMJ Rapid Recommendations project, a collaborative effort from the MAGIC Evidence Ecosystem Foundation (www.magicevidence.org) and the $B M J .^{18} \mathrm{~A}$ guideline panel helped define the study question and selected adverse events for review. The adverse events of interest include psychiatric and cognitive adverse events, injuries and accidents, and dependence and withdrawal. It is one of four systematic reviews that together informed a parallel guideline on medical cannabis and cannabinoids published on bmj.com and the MAGICapp. ${ }^{11}{ }^{19-21}$ A parallel systematic review addressed evidence from randomized trials. $^{11}$ 
medRxiv preprint doi: https://doi.org/10.1101/2021.05.27.21257921; this version posted May 29, 2021. The copyright holder for this preprint (which was not certified by peer review) is the author/funder, who has granted medRxiv a license to display the preprint in perpetuity. It is made available under a CC-BY-NC-ND 4.0 International license .

153 We report our systematic review in accordance with the PRISMA Harms Checklist. ${ }^{22}$ We registered the protocol for our review at OSF (https://osf.io/25bxf). ${ }^{22}$

\section{Guideline panel involvement}

156 A guideline panel helped define the study question and selected the adverse events for review. The 157 panel included nine content experts (two general internists, two family physicians, a pediatrician, a 158 physiatrist, a pediatric anesthesiologist, a clinical pharmacologist, and a rheumatologist), nine methodologists (five of whom are also front-line clinicians), and three people living with chronic pain (one of whom used cannabinoids for medical purposes).

\section{Patient and public involvement}

162 Three patient partners were included as part of the guideline panel and contributed to the selection and prioritization of outcomes, protocol, and interpretation of review findings, and provided insight on 164 values and preferences.

Search

166 A medical librarian searched MEDLINE, EMBASE, PsychInfo, and Cochrane Central Register of Controlled 167 Trials (CENTRAL) from inception to April 1, 2020, with no restrictions on language, for non-randomized 168 studies reporting on harms or adverse events of medical cannabis or cannabinoids for chronic pain 169 (Appendix 1). We scanned reference lists of relevant reviews to identify any eligible studies not retrieved 170 by our electronic search and solicited content experts from our panel for unpublished studies.

\section{Study selection}

172 Reviewers, working independently and in duplicate, reviewed titles and abstracts of search records and 173 subsequently full texts of records found potentially eligible at the title and abstract screening stage.

174 Reviewers resolved disagreements by discussion or by adjudication by a third reviewer (DZ).

175 We included all non-randomized studies that reported on any patient-important harm or adverse event 176 associated with the use of any formulation of medical cannabis or cannabinoids in adults or children, 177 living with chronic pain (pain lasting for $\geq 3$ months) or a medical condition associated with chronic pain 
medRxiv preprint doi: https://doi.org/10.1101/2021.05.27.21257921; this version posted May 29, 2021. The copyright holder for this preprint (which was not certified by peer review) is the author/funder, who has granted medRxiv a license to display the preprint in perpetuity. It is made available under a CC-BY-NC-ND 4.0 International license .

178 (i.e., fibromyalgia, arthritis, multiple sclerosis, neuropathy, inflammatory bowel disease, stroke, or 179 advanced cancer) or that compared adverse events associated with medical cannabis or cannabinoids 180 with another pharmacologic or non-pharmacologic intervention. Based on input from the guideline 181 panel, we excluded studies in which patients used cannabis for less than 4 weeks because we 182 anticipated that four weeks would be the minimum amount of time after which we would reasonably 183 expect to observe potential serious or long term harms associated with medical cannabis. ${ }^{23}$ We looked for explicit statements or evidence that patients were experiencing chronic pain. We excluded studies in which: (1) fewer than 25 patients used medical cannabis or cannabinoids, (2) patients did not suffer from chronic pain or a condition that commonly causes chronic pain or more than $20 \%$ of patients reported using medical cannabis or cannabinoids for a condition other than chronic pain, (3) patients were using medical cannabis for recreational reasons, (4) only surrogate measures of patient-important harms and adverse effects (e.g., performance on cognitive tests, lab values) were reported, and (5) systematic reviews and other types of studies that did not describe primary data.

\section{Data extraction and risk of bias}

192 Reviewers, working independently and in duplicate and using a standardized and pilot-tested data 193 collection form, extracted the following information from each eligible study: (1) study design, (2) patient characteristics (age, sex, condition/diagnosis), (3) characteristics of medical cannabis or cannabinoids (name of product, dose, and duration), and (4) number of patients that experienced adverse events, including all adverse events, serious adverse events, and withdrawal due to adverse events. We classified adverse events as serious based on the classification used in primary studies. For comparative studies, we collected results from models adjusted for confounders, when reported, and unadjusted models when results for adjusted models were not reported.

When studies reported the number of events rather than the number of patients experiencing adverse events, we only extracted the number of events if they were infrequent (the number of events accounted for less than $10 \%$ of the total number of study participants). For studies that reported on adverse events at multiple timepoints, we extracted data for the longest point of follow-up that

204 included, at minimum, $80 \%$ of the patients recruited into the study. Reviewers resolved disagreements 205 by discussion or by adjudication with a third reviewer (DZ).

206 We used the Cochrane-endorsed ROBINS-I tool to rate the risk of bias of studies as low, moderate, 207 serious, or critical across seven domains: (1) bias due to confounding, (2) selection of patients into the 
medRxiv preprint doi: https://doi.org/10.1101/2021.05.27.21257921; this version posted May 29, 2021. The copyright holder for this preprint (which was not certified by peer review) is the author/funder, who has granted medRxiv a license to display the preprint in perpetuity. It is made available under a CC-BY-NC-ND 4.0 International license .

study, (3) classification of the intervention, (4) bias due to deviations from the intended intervention, (5) missing data, (6) measurement of outcomes, and (7) selection of reported results. ${ }^{24}$ Appendix 2 presents additional details on the assessment of risk of bias. Studies were rated at low risk of bias overall when all domains were at low risk of bias; moderate risk of bias if all domains were rated at low or moderate risk of bias; at serious risk of bias when all domains were rated either at low, moderate, or serious risk of bias; and at critical risk of bias when one or more domains were rated as critical.

\section{Data synthesis}

In this review, we synthesize data on serious adverse events and adverse events that may emerge with longer duration of medical cannabis use for which data is typically not reported in randomized trials. Identified by a parallel BMJ Rapid Recommendations guideline panel as important, these patientimportant outcomes included psychiatric and cognitive adverse events, injuries and accidents, and dependence and withdrawal. Data on all other adverse events reported in primary studies are available in an open-access database (https://osf.io/ut36z/).

Adverse events are reported as binary outcomes. For comparative studies, when possible, we present risk differences and associated 95\% confidence intervals (95\% Cls). Since there were only two eligible comparative studies each with different comparators, we did not perform meta-analysis. For single-arm studies, we pooled the proportion of patients experiencing adverse events of interest by first applying a Freeman-Tukey type arcsine square root transformation to stabilize the variance. Without this transformation, very high or very low prevalence estimates can produce confidence intervals that contain values lower than $0 \%$ or higher than $100 \%$. All meta-analyses used DerSimonian-Laird randomeffects models, which are conservative as they consider both within- and between-study variability. ${ }^{25-27}$ We evaluated heterogeneity for all pooled estimates through visual inspection of forest plots and calculation of tau-squared $\left(\tau^{2}\right)$, because some statistical tests of heterogeneity ( $I^{2}$ and Cochrane's $\left.Q\right)$ can be misleading when sample sizes are large and $\mathrm{Cls}$ are therefore narrow. ${ }^{28}$ For studies that reported estimates for all-cause adverse events and those deemed to be potentially related to cannabis use, we preferentially synthesized results for all adverse events.

For analyses for which we observed high clinical heterogeneity (i.e., substantial differences in the estimates of individual studies and minimal overlap in the confidence intervals), we presented results narratively. 
medRxiv preprint doi: https://doi.org/10.1101/2021.05.27.21257921; this version posted May 29, 2021. The copyright holder for this preprint (which was not certified by peer review) is the author/funder, who has granted medRxiv a license to display the preprint in perpetuity. It is made available under a CC-BY-NC-ND 4.0 International license .

237 We classified adverse events as serious based on the classification used in primary studies.

238 We performed tests of interaction to establish whether subgroups differed significantly from one

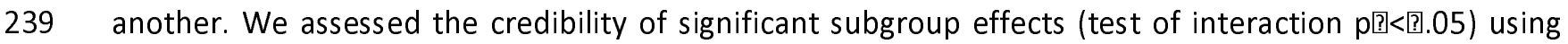
published criteria. ${ }^{29} 30$

241 We performed all analyses using the 'meta' package in R (version 3.5.1, R Foundation for Statistical 242 Computing). ${ }^{31}$

\section{Certainty of evidence}

244 We used the GRADE approach to rate the certainty of evidence. ${ }^{32} 33$ Based on GRADE guidance for using the ROBINS-I tool, evidence starts at high certainty and is downgraded by one level when the majority of the evidence comes from studies at moderate risk of bias, two levels when the majority of the evidence comes from studies at high risk of bias, and three levels when the majority of the evidence comes from studies rated at critical risk of bias. ${ }^{32}$ We additionally considered potential limitations due to indirectness if the population, intervention, or adverse events assessed in studies did not reflect the populations, interventions, or adverse events of interest, inconsistency if there was important unexplained differences in the results of studies, and imprecision if the upper and lower bounds of confidence intervals indicated appreciably different rates of adverse events. For assessing inconsistency and imprecision for the outcome all adverse events, based on feedback from the guideline panel, we deemed a $20 \%$ difference in the prevalence of all adverse evidence to be patient-important; a $10 \%$ difference for adverse events leading to discontinuation, serious adverse events, and psychiatric, cognitive, withdrawal and dependence, injuries; and a 3\% difference for potentially fatal adverse events, such as suicides and motor vehicle accidents. We followed GRADE guidance for communicating our findings. ${ }^{34}$ Guideline panel members interpreted the magnitude of adverse events and decided whether the observed prevalence of adverse events was sufficient to affect patients' decisions to use medical cannabis or cannabinoids for chronic pain.

\section{Results}

\section{Study selection}

263 Our search yielded 17,178 unique records of which 39 were eligible for review (Figure 1, Appendix 3). ${ }^{35-}$

$264{ }^{73}$ Appendix 4 presents studies excluded at the full-text screening stage and accompanying reasons for 265 exclusion. 
medRxiv preprint doi: https://doi.org/10.1101/2021.05.27.21257921; this version posted May 29, 2021. The copyright holder for this preprint (which was not certified by peer review) is the author/funder, who has granted medRxiv a license to display the preprint in perpetuity.

It is made available under a CC-BY-NC-ND 4.0 International license .

\section{Description of studies}

267 Studies included 12,143 adults living with chronic pain and included a median of 100 (IQR 34 to 361) 268 participants (Table 1). Most studies (30/39; 76.9\%) were longitudinal in design. Eighteen studies (46.2 \%) 269 were conducted in Western Europe, fourteen (35.9\%) in North America, six (15.4\%) in Israel, and two $270(5.1 \%)$ in the United Kingdom. Ten studies (25.6\%) were funded by industry alone or industry in 271 combination with government and institutional funds; the remainder were funded either by 272 governments, institutions, or not-for-profit organizations ( $n=9 ; 23.1 \%$ ), did not receive funds ( $n=3$;

$2737.7 \%$ ), or did not report funding information ( $n=17 ; 43.6 \%$ ).

274 Thirty studies (76.9\%) reported on people living with chronic non-cancer pain, eight ( $\mathrm{n}=20.5 \%$ ) with 275 mixed cancer and non-cancer chronic pain, and one (2.6\%) with chronic cancer pain. All studies reported 276 on adults. Sixteen studies reported on mixed types of herbal cannabis (e.g., buds for smoking, 277 vaporizing, and ingesting, hashish, oils, extracts, edibles), nine on palmitoylethanolamide (PEA), four 278 each on nabiximols and dronabinol, two on nabilone, one each on Trokie lozenges and extracts, and four 279 did not report the type of medical cannabis used. One study reported on three types of medical 280 cannabis (dronabinol, nabiximols, and mixed herbal) separately. The median duration of medical 281 cannabis use was 24 weeks (IQR 12.0 to 33.8 weeks). Two studies were comparative: one study compared nabilone with gabapentin and another compared herbal cannabis with standard care. ${ }^{39} 48$ Studies reported a total of 525 unique adverse events.

\section{Risk of bias}

285 Appendix 5 presents the risk of bias of included studies. We rated all results at critical risk of bias except 286 for the comparative results from two studies, ${ }^{39} 48$ which were rated at serious and moderate risk of bias.

287 The primary limitation across studies was inadequate control for potential confounding either due to the 288 absence of a control group or inadequate adjustment for confounders. A third of studies were rated at 289 serious risk of bias for selection bias, primarily because they included prevalent users of medical 290 cannabis. Such studies may underestimate the incidence of adverse events since patients that 291 experience adverse events are more likely to discontinue medical cannabis early. Such studies may also 292 include adverse events that may have been present at inception and that are unrelated to medical 293 cannabis use. 
medRxiv preprint doi: https://doi.org/10.1101/2021.05.27.21257921; this version posted May 29, 2021. The copyright holder for this preprint (which was not certified by peer review) is the author/funder, who has granted medRxiv a license to display the preprint in perpetuity. It is made available under a CC-BY-NC-ND 4.0 International license .

\section{All adverse events}

295 Twenty longitudinal and two cross-sectional studies, including 4,108 patients, reported the number of 296 patients experiencing one or more adverse events. ${ }^{36-4346475456-60626465697073}$ Seven studies reported on

297 PEA, five on mixed herbal cannabis, three each on nabilone and nabiximols, two on dronabinol, and one 298 each on extracts and Trokie lozenges. The median duration of medical cannabis use was 24 weeks [IQR 29912 to 32]. We observed substantial unexplained heterogeneity and so summarize the results descriptively (Appendices 6 to 9). The prevalence of any adverse event ranged between 0\% to $92.1 \%$.

301 Studies with less than 24 weeks of cannabis use typically reported fewer adverse events than those with 302 more than 24 weeks. Patients using PEA experienced no adverse events. The evidence was overall very 303 uncertain due to risk of bias and inconsistency.

304 One study suggested that nabilone may reduce the risk of adverse events compared to gabapentin ($30513.1 \% ; 95 \% \mathrm{Cl}-26.2$ to 0 ), but the certainty of evidence was very low due to risk of bias and imprecision 306 (Table 2).

\section{Adverse events leading to discontinuation}

308 Twenty longitudinal studies, including 6,509 patients, reported on the number of patients that 309 discontinued medical cannabis or cannabinoids due to adverse events. 3739 41-44 46-49 52545657596263657073 310 Eight studies reported on PEA, four studies on mixed herbal cannabis, three on nabiximols, two on 311 nabilone, and one each on dronabinol and extracts, and one study did not report the type of medical 312 cannabis used by patients. The median duration of cannabis use was 24 weeks [IQR 8.6 to 32]. We 313 observed substantial unexplained heterogeneity and so summarize the results descriptively (Appendices 31410 to 12 ). The prevalence of discontinuations due to adverse events ranged between $0 \%$ to $27.0 \%$. 315 Studies with less than 24 weeks of cannabis use typically reported fewer discontinuations than those 316 with more than 24 weeks. Patients using PEA experienced no adverse events. The evidence was overall 317 very uncertain due to risk of bias and inconsistency.

318 One study suggested herbal cannabis may increase the risk of adverse events leading to discontinuation 319 compared to standard care without cannabis (4.7\%; $95 \% \mathrm{Cl} 1.8$ to 7.5 ). Another study suggested that 320 nabilone may reduce the risk of adverse events leading to discontinuation compared to gabapentin ($3219.4 \% ; 95 \% \mathrm{Cl}-18.5$ to -0.2 ). The certainty of evidence was low to very low due to risk of bias and 322 imprecision. 
medRxiv preprint doi: https://doi.org/10.1101/2021.05.27.21257921; this version posted May 29, 2021. The copyright holder for this preprint (which was not certified by peer review) is the author/funder, who has granted medRxiv a license to display the preprint in perpetuity. It is made available under a CC-BY-NC-ND 4.0 International license .

\section{Serious adverse events}

324 Twenty-two longitudinal and two cross-sectional studies, including 4,273 patients, reported on the number of patients experiencing one or more serious adverse events. ${ }^{35-3739-434648495254-606265707173}$ Eight studies reported on mixed herbal cannabis, eight on PEA, two each on nabilone and nabiximols each, and one study each on dronabilon, extracts, and Trokie lozenges, and one study did not report the type of cannabis used. The median duration of medical cannabis or cannabinoid use was 24 weeks (IQR 12 to 32 ), and few patients experienced serious adverse events (1.2\%; 95\% $\mathrm{Cl} 0.1$ to $3.1 ; \mathrm{I}^{2}=91 \%$ ) (Figure 2) (Appendices 13 to 15). There was a statistically significant subgroup effect across different types of medical cannabis though serious adverse events appeared consistently uncommon among different types (low credibility). The certainty of evidence was very low overall due to serious risk of bias.

One study suggested herbal cannabis increased the risk of serious adverse events compared to standard care without cannabis (1.5\%; $95 \% \mathrm{Cl}-8.3$ to 20.2 ). Another study found use of nabilone vs. gabapentin showed no difference in the risk of serious adverse events. The certainty of evidence was low to very low for both studies due to risk of bias and imprecision.

\section{Psychiatric adverse events}

338 Eleven longitudinal and two cross-sectional studies, including 6,600 patients, reported on any psychiatric adverse events, including psychiatric disorders, suicide, suicidal thoughts, depression, mania, hallucinations, delusions, paranoia, anxiety, and euphoria (Appendices 16 to 25). ${ }^{35-374347486063676870}$ Five studies reported on mixed herbal cannabis, four on nabiximols, one each on dronabinol, nabilone, and mixed types and one study did not specify the type of medical cannabis. The median duration of cannabis use across studies was 52 weeks (IQR 20 to 52). Approximately one in seven medical cannabis users experienced one or more psychiatric disorders or adverse events (13.5\%; $95 \% \mathrm{Cl} 2.6$ to 30.6 ;

$\left.345 \quad I^{2}=98 \%\right)$. The most frequently occurring psychiatric adverse events were paranoia (5.6\%; $9 \% \mathrm{Cl} 0$ to 19.2 ;

$\left.346 \quad I^{2}=85 \%\right)$ and anxiety (7.4\%; $95 \% \mathrm{Cl} 0$ to $\left.26.9 ;\left.\right|^{2}=99 \%\right)$. The certainty of evidence was very low due to risk

347 of bias, inconsistency (for psychiatric disorders and paranoia), and imprecision (for psychiatric disorder, 348 paranoia, and anxiety).

349 One study suggested that herbal cannabis may result in a trivial to moderate increase in the risk for 350 psychiatric disorders, mania, hallucinations, depression, paranoia, anxiety, and euphoria and a reduction 351 in the risk for suicides and delusions, compared with standard care without cannabis, though the 352 certainty of evidence was low to very low due to risk of bias and imprecision. 
medRxiv preprint doi: https://doi.org/10.1101/2021.05.27.21257921; this version posted May 29, 2021. The copyright holder for this preprint (which was not certified by peer review) is the author/funder, who has granted medRxiv a license to display the preprint in perpetuity.

It is made available under a CC-BY-NC-ND 4.0 International license .

\section{Cognitive and attentional adverse events}

354 Eleven longitudinal studies, including 6,257 patients, reported on cognitive adverse events, including memory impairment, confusion, disorientation, and impaired attention (Appendices 26 to 29). ${ }^{35-37434748}$ cannabis, and one each on dronabinol and nabilone. The median duration of cannabis use was 52 weeks (IQR 24 to 52). The prevalence of cognitive adverse events ranged from $1.6 \%$ (95\% $\mathrm{Cl} 0.6$ to $3.0 ; I^{2}=88 \%$ ) to $5.3 \%\left(95 \% \mathrm{Cl} 2.1\right.$ to $\left.9.6 ; \mathrm{I}^{2}=96 \%\right)$ for disorientation and memory impairment, respectively. The certainty of evidence was very low due to risk of bias.

One study suggests herbal cannabis may slightly increase the risk for memory impairment and disturbances in attention compared to standard care without cannabis, but reduce the risk for confusion, though the certainty of evidence was low to very low due to risk of bias and imprecision.

\section{Accidents and injuries}

365 One longitudinal study, including 431 patients, reported on accidents and injuries in patients using mixed herbal cannabis for 52 weeks (Appendices $30 \& 31$ ). ${ }^{48}$ This study suggests herbal cannabis used 367 for medical purposes may slightly increase the risk of motor vehicle accidents $(0.5 \% ; 95 \% \mathrm{Cl}-0.4$ to 1.4$)$ but may not increase the risk of falls $(0 \% ; 95 \% \mathrm{Cl}-2.8$ to 2.9$)$. The certainty of evidence was low due to risk of bias.

371 Four longitudinal and one cross-sectional study, including 2,248 patients, reported on dependence372 related adverse events, including dependence (one study reported on 'abuse' based on unspecified 373 criteria, one study reported on 'problematic use' using the Alcohol Use Disorder and Associated 374 Disabilities Interview Schedule-Diagnostic and Statistical Manual of Mental Disorders-Fourth Edition 375 (AUDADIS-IV) $^{74}$, and one study reported on 'dependence' using the Alcohol, Smoking, and Substance 376 Involvement Screening Test ${ }^{75}$ ), withdrawal symptoms (defined as one or moderate or severe withdrawal 377 symptoms including sleep difficulties, anxiety, irritability, and appetite disturbance), and withdrawal 378 syndrome (two studies that used unspecified criteria) (Appendices 32 to 34). ${ }^{48} 53566770$ Two studies 379 reported on herbal cannabis, one each on nabiximols and nabilone, and one did not specify type of medical cannabis used by patients. Follow-up ranged from 12 to 52 weeks. Though dependence and withdrawal syndrome were uncommon with a prevalence of $4.4 \%\left(95 \% \mathrm{Cl} 0.0\right.$ to $\left.19.9 ; \mathrm{I}^{2}=99 \%\right)$ and $2.1 \%$ 
medRxiv preprint doi: https://doi.org/10.1101/2021.05.27.21257921; this version posted May 29, 2021. The copyright holder for this preprint (which was not certified by peer review) is the author/funder, who has granted medRxiv a license to display the preprint in perpetuity. It is made available under a CC-BY-NC-ND 4.0 International license .

(95\% $\mathrm{Cl} 0$ to $\left.8.2 ; \mathrm{I}^{2}=89 \%\right)$, respectively, withdrawal symptoms were common $(67.8 \% ; 95 \% \mathrm{Cl} 64.1$ to 71.4). The certainty of evidence was very low due to risk of bias, inconsistency, imprecision (for dependence), and indirectness due to definitions of outcomes in studies were too vague to confidently distinguish between dependence, addiction, withdrawal symptoms, and withdrawal syndrome.

One study suggested that herbal cannabis compared to standard care may slightly increase the risk of withdrawal syndrome $(0.5 \% ; 95 \% \mathrm{Cl}-0.4$ to 1.4$)$ but the certainty of evidence was low due to risk of bias.

\section{Discussion}

\section{Main findings}

Our systematic review and meta-analysis provides evidence that adverse events are common among people living with chronic pain who use medical cannabis or cannabinoids, with approximately one in four experiencing at least one adverse event-though the certainty of evidence is very low and the true prevalence of adverse events may be substantially different. In contrast, serious adverse events, adverse events leading to discontinuation, cognitive adverse events, accidents and injuries, and dependence and withdrawal syndrome are uncommon. We compared studies with $<24$ weeks and $\geq 24$ weeks cannabis use and found more adverse events reported among studies with longer follow-up. This may be explained by increased tolerance (tachyphylaxis) with prolonged exposure, necessitating increases in dosage with consequent increased risk of harms. PEA, compared to other formulations of medical cannabis, may result in the fewest adverse events. Though adverse events appear to be common, few patients discontinued medical cannabis due to adverse events suggesting that most adverse events are transient and/or outweighed by perceived benefits.

Our review represents the most comprehensive review of evidence from non-randomized studies addressing adverse events of medical cannabis or cannabinoid use in people living with chronic pain. While several previous reviews have summarized the evidence on short-term and common adverse events of medical cannabis reported in randomized trials, such as oral discomfort, dizziness, and headaches, our review focuses on serious and rare adverse events-the choice of which was informed by a panel including patients, clinicians, and methodologists-and non-randomized studies, which can follow larger numbers of patients for longer periods of time and thus may detect adverse events that are infrequent or that are associated with longer durations of cannabis use. ${ }^{10} 76-80$ A parallel systematic review of evidence from randomized controlled trials found no evidence to inform long-term harms of medical cannabis as no eligible trial followed patients for more than 5.5 months. ${ }^{11}$ One previously 
medRxiv preprint doi: https://doi.org/10.1101/2021.05.27.21257921; this version posted May 29, 2021. The copyright holder for this preprint (which was not certified by peer review) is the author/funder, who has granted medRxiv a license to display the preprint in perpetuity. It is made available under a CC-BY-NC-ND 4.0 International license .

412 published review that included non-randomized studies searched the literature until 2007, included 413 studies exploring medical cannabis for any indication (excluding synthetic cannabinoids) of which only 414 two enrolled people living with chronic pain. ${ }^{12}$ The review also did not synthesize adverse event data 415 from non-randomized studies. ${ }^{12}$ Unlike previous reviews, we focused exclusively on medical cannabis for 416 chronic pain and excluded recreational cannabis, because cannabis used for recreational purposes often 417 contains higher concentrations of tetrahydrocannabinol (THC) than medical cannabis. We also focused 418 on chronic pain because this patient population may be susceptible to different adverse events. 419 Depression and anxiety, for example, are commonly occurring comorbidities of chronic pain, which may 420 be exacerbated by cannabis. ${ }^{15-17}$

\section{Strengths and limitations}

422 Strengths of this systematic review and meta-analysis include a comprehensive search for non423 randomized studies, explicit eligibility criteria, screening of studies and collection of data in duplicate to 424 increase reliability, and use of the GRADE approach to evaluate the certainty of evidence.

425 Our review is limited by the non-comparative design of most studies, which precludes confident 426 inferences regarding the proportion of adverse events that can be attributed to medical cannabis or 427 cannabinoids and the magnitude by which medical cannabis may increase or decrease the risk of 428 adverse events compared to other pain management options. Though adverse events appear common 429 among medical cannabis users, it is possible that other management options for chronic pain, 430 particularly opioids, may be associated with more (and more severe) adverse events. ${ }^{81}$ Partly due to the 431 non-comparative design of most studies, nearly all results included in our review were at serious or 432 critical risk of bias for confounding, either due to the absence of a control group or due to insufficient 433 adjustment for important confounders. Further, a third of studies were at high risk of selection bias, 434 primarily because they included prevalent cannabis users. In such studies, the prevalence of adverse 435 events may be underestimated. Our review provides limited evidence on the harms of medical cannabis 436 beyond one year of use since most studies reported adverse events for less than one year of follow-up.

437 We observed some inconsistency for many adverse events of interest and substantial inconsistency for 438 all adverse events and adverse events leading to discontinuation. We downgraded the certainty of 439 evidence when we observed important inconsistency and we did not present estimates from meta440 analyses for all adverse events and adverse events leading to discontinuation due to substantial 441 inconsistency. 
medRxiv preprint doi: https://doi.org/10.1101/2021.05.27.21257921; this version posted May 29, 2021. The copyright holder for this preprint (which was not certified by peer review) is the author/funder, who has granted medRxiv a license to display the preprint in perpetuity. It is made available under a CC-BY-NC-ND 4.0 International license .

Sixteen of 39 studies reported on herbal medical cannabis, some of which were consumed by smoking or vaporizing, and may be associated with different adverse events (e.g. respiratory) than other formulations of medical cannabis. We attempted to perform subgroup analyses based on the type of medical cannabis. Results for subgroups, however, lacked credibility due to inconsistency and/or imprecision.

Clinicians and patients may be more inclined to use medical cannabis or cannabinoids for pain relief if adverse events are mild; however, the evidence on whether adverse events are transient, life threatening, or the extent to which they impact quality of life is limited. While more than half of studies reported on the proportion of adverse events that were serious, criteria for ascertaining severity were rarely reported. None of the included studies reported the duration for which patients experienced adverse events. Further, most primary studies did not report adequate details on methods for the ascertainment of adverse events, including definitions or diagnostic criteria. The two studies that reported on withdrawal syndrome, for example, did not provide diagnostic criteria. ${ }^{48} 56$ However, the DSM-5 requires $\geq 3$ of 7 withdrawal symptoms to be present within a week of stopping cannabis use to meet a diagnosis of cannabis withdrawal syndrome. ${ }^{82}$ It is therefore reasonable that people living with chronic pain that use medical cannabis would be more likely to experience withdrawal symptoms vs. withdrawal syndrome.

While children and youth account for approximately $15 \%$ of all chronic pain patients, we did not identify any evidence addressing the harms of medical cannabis in this population. ${ }^{83}$ As such, the extent to which our findings are generalizable to pediatric populations is uncertain. Although there is evidence that cannabis use during youth is associated with increased risk of acute psychotic disorders, particularly acute psychosis, ${ }^{84}$ such studies have explored use of recreational cannabis that contains greater amounts of THC than is typically seen in medical preparations. Further, the population of patients with chronic pain on which the studies report may not be representative of all patients with chronic painparticularly rare conditions that cause chronic pain.

Finally, we excluded studies from meta-analyses when they did not explicitly report the adverse events of interest to our panel members. This may have overestimated the prevalence of adverse events if the adverse events of interest were not observed in the studies in which they were not reported. This was, however, not possible to confirm because methods for the collection and reporting of adverse event 
medRxiv preprint doi: https://doi.org/10.1101/2021.05.27.21257921; this version posted May 29, 2021. The copyright holder for this preprint (which was not certified by peer review) is the author/funder, who has granted medRxiv a license to display the preprint in perpetuity. It is made available under a CC-BY-NC-ND 4.0 International license .

471 data across studies were variable (e.g., active monitoring vs. passive surveillance; collecting data on

472 specific adverse events vs. all adverse events) and poorly described in study reports.

\section{Implications}

474 Our systematic review and meta-analysis shows that evidence regarding long-term and serious harms of 475 medical cannabis or cannabinoids is insufficient-an issue with important implications for patients and 476 clinicians considering this management option for chronic pain. While the evidence suggests that 477 adverse events are common in patients using medical cannabis for chronic pain, serious adverse events 478 appear uncommon, which suggests that the potential benefits of medical cannabis or cannabinoids 479 (although very modest) may outweigh potential harms for some patients. ${ }^{11} 21$

480

481

482

483

484

485 486

Clinicians and patients considering medical cannabis should be aware that more adverse events were reported among studies with longer follow-up, necessitating long term follow-up of patients and reevaluation of pain treatment options. Our findings also have implications for the choice of medical cannabis. We found PEA, for example, to consistently be associated with few or no adverse events across studies, though the evidence on the efficacy of PEA is limited. ${ }^{11}$

We found very limited evidence comparing medical cannabis or cannabinoids with other pain management options. Other pharmacological treatments for chronic pain, such as gabapentinoids, antidepressants, and opioids, may be associated with more (and more serious) adverse events. ${ }^{85-87}$ To guide patients' and clinicians' decisions on medical cannabis for chronic pain, future research should compare the harms of medical cannabis and cannabinoids with other pain management options, including opioids, ideally beyond one year of use, and adjust results for confounders. Future research could also explore whether the harms of medical cannabis vary depending on the type of chronic pain.

Our review highlights the need for standardization of reporting of adverse events in non-randomized studies since such studies represent a critical source of data on long-term and infrequently occurring harms. To enhance the interpretability of adverse event data, future studies should also report the duration and severity of adverse events, since these factors are important to patients' decisions.

A valuable output of our systematic review is an open-source database of over 500 unique adverse events reported to date in non-randomized studies of medical cannabis or cannabinoids for chronic pain with corresponding assessments of risk of bias. This database was compiled in duplicate by trained and calibrated data extractors and is freely available to those interested in further analyzing the prevalence 
medRxiv preprint doi: https://doi.org/10.1101/2021.05.27.21257921; this version posted May 29, 2021. The copyright holder for this preprint

(which was not certified by peer review) is the author/funder, who has granted medRxiv a license to display the preprint in perpetuity.

It is made available under a CC-BY-NC-ND 4.0 International license .

500 of different types of adverse or to those interested in expanding the database to include adverse events

501 in patients using medical cannabis or cannabinoids for other indications.

\section{Conclusion}

503 Our systematic review and meta-analysis found very low certainty evidence that suggests that adverse

504 events are common among people living with chronic pain using medical cannabis or cannabinoids, but

505 that serious adverse events, adverse events causing discontinuation, cognitive adverse events, motor

506 vehicle accidents, falls, and dependence and withdrawal syndrome are uncommon. We also found very

507 low certainty evidence that longer duration of use was associated more adverse events and that PEA,

508 compared with other types of medical cannabis, may result in few or no adverse events. Future research

509 should compare the risks of adverse events of medical cannabis and cannabinoids with alternative pain

510 management options, including opioids, and adjust for potential confounders. 


\section{Tables}

\section{Table 1: Study characteristics}

\section{Study \\ Design}

Country

Condition

Cannabis/
comparator

cross-sectional*

Ware, $2003^{35}$

Canada

mixed non-cancer pain

mixed herbal

canda

mixed non-cancer pain

UK

multiple sclerosis

mixed non-cancer pain

Weber, $2009^{38}$

Bestard, $2011^{39}$

longitudinal*†

longitudinal* $^{*}$

Germany

peripheral neuropathic pain

cross-sectional*

Fiz, $2011^{40}$

Dominguez, $2012^{41}$

Gatti, $2012^{42}$

Toth, $2012^{43}$

Schifilliti, $2014^{44}$

Storr, $2014^{45}$

Del Giorno, $2015{ }^{46}$

Hoggart, $2015^{47}$

Ware, $2015^{48}$

longitudinat

Spain

fibromyalgia

longitudinal*

longitudinalt+

longitudinal*†

longitudinalt†

cross-sectional*

longitudinalt+

longitudinal+†

longitudinal*†

gabapentin

mixed herbal

Spain lumbosciatica mixed cancer and non-cancer pain

nabilone

Crohn's disease $(n=42)$,

ulcerative colitis $(n=10)$

mixed herbal

$$
\text { fibromyalgia }
$$

PEA

$$
\text { Italy }
$$

diabetic neuropathy

nabiximols

mixed non-cancer pain

mixed herbal frequency: rarely ( $n=9)$, weekly $(n=8)$, daily
\[ (n=5),>\text { once daily }(n=7) \]

$$
(n=5) \text {, >once daily }(n=7)
$$

dose: $1-2$ puffs ( $n=4), 3-4$ puffs ( $n=13$ ), whole joint $(n=8)$, more than one joint $(n=4)$

\section{\# of participants}

Duration of

cannabis use (weeks)

32

NR mean: $2.5 \mathrm{~g} /$ day mean: 7.5 sprays/day median: $7.5 \mathrm{mg} /$ day

mean: $3.0 \mathrm{mg} / \mathrm{day}$

mean: $2.3 \mathrm{~g} / \mathrm{day}$

$\sim 1$ to 2 cigarettes or spoonful

daily ( $n=12$ ) once every 2 to 4 days ( $n=5)$, less than twice a week $(n=3)$, or occasionally $(n=8)$

$$
300 \mathrm{mg} \text { bid }
$$

$600 \mathrm{mg}$ bid three weeks; $600 \mathrm{mg} /$ day for four weeks

mean: $2.85 \mathrm{mg} /$ day

$300 \mathrm{mg}$ bid

\section{NR} indeterminate colitis $(n=4)$

600 


\begin{tabular}{|c|c|c|c|c|c|c|c|}
\hline & & & & standard care & & 216 & \\
\hline Haroutounian, $2016^{49}$ & longitudinal* & Israel & $\begin{array}{l}\text { mixed cancer and non-cancer } \\
\text { pain }\end{array}$ & mixed herbal & mean: $43.2 \mathrm{~g} /$ month & 206 & 30 \\
\hline & longitudinal* & & & & Capsule: $10 \mathrm{mg} / 8$ to 10 hours & & \\
\hline Bellnier, $2017^{50}$ & & US & $\begin{array}{l}\text { mixed cancer and non-cancer } \\
\text { pain }\end{array}$ & mixed herbal & $\begin{array}{c}\text { Vapor pen inhaler for breakthrough pain: } 2 \mathrm{mg} \\
\text { THC, } 0.1 \mathrm{mg} \text { CBD; } 1 \text { to } 5 \text { puffs every } 15 \\
\text { minutes until pain relief; could be used every } \\
4 \text { to } 6 \text { hours }\end{array}$ & 29 & 12 \\
\hline & cross-sectional* & & & & $0(n=69),<1 / 8$ oz/week $(n=130), 1 / 8$ to $1 / 4$ & & \\
\hline Cranford, $2017^{51}$ & & US & mixed non-cancer pain & NR & $\begin{array}{c}\text { oz/week }(n=156), 1 / 4 \text { to } 1 / 2 \text { oz/week }(n=179), \\
1 / 2 \text { to } 1 \text { oz/week }(n=122), 1 \text { or more oz/week } \\
\text { ( } n=115)\end{array}$ & 775 & NR \\
\hline Fanelli, $2017^{52}$ & longitudinalt† & Italy & $\begin{array}{l}\text { mixed cancer and non-cancer } \\
\text { pain }\end{array}$ & mixed herbal & $\begin{array}{c}\text { mean: } 69.5 \mathrm{mg} / \text { day bediol; } 67.0 \mathrm{mg} / \text { day } \\
\text { bedrocan }\end{array}$ & 341 & mean: 14.01 \\
\hline Feingold, $2017^{53}$ & cross-sectional* & Israel & $\begin{array}{l}\text { mixed cancer and non-cancer } \\
\text { pain }\end{array}$ & mixed herbal & NR & 406 & NR \\
\hline Paladini, $2017^{54}$ & longitudinalt† & Italy & failed back surgery syndrome & PEA & $\begin{array}{l}600 \mathrm{mg} \text { bid for one month; } 600 \mathrm{mg} / \text { day for } \\
\text { one month }\end{array}$ & 35 & 8 \\
\hline Passavanti, $2017^{55}$ & longitudinal†† & Italy & lower back pain & PEA & $600 \mathrm{mg}$ bid & 30 & 24 \\
\hline Schimrigk, $2017^{56}$ & longitudinal ${ }^{* \dagger}$ & Germany, Austria & multiple sclerosis & dronabinol & range: 7.5 to $15 \mathrm{mg} / \mathrm{day}$ & 209 & 32 \\
\hline Chirchiglia, $2018^{57}$ & longitudinal†† & Italy & lower back pain & PEA & $1.2 \mathrm{~g} / \mathrm{day}$ & 100 & 4 \\
\hline Crowley, $2018^{58}$ & longitudinal* & US & mixed non-cancer pain & Trokie lozenges & NR & 35 & 4 to 60 \\
\hline Habib, $2018^{59}$ & longitudinal* & Israel & fibromyalgia & mixed herbal & mean: $26 \mathrm{~g} /$ month & 26 & mean: 41.6 \\
\hline Anderson, $2019^{60}$ & longitudinal* & US & cancer pain & mixed herbal & NR & 1120 & 16 \\
\hline Bonar, $2019^{61}$ & $\begin{array}{c}\text { cross- } \\
\text { sectionalt+ }\end{array}$ & US & mixed non-cancer pain & NR & $\begin{array}{c}0(n=95),<1 / 8 \text { oz/week }(n=126), 1 / 8 \text { to } 1 / 4 \\
\text { oz/week }(n=158), 1 / 4 \text { to } 1 / 2 \text { oz/week }(n=174), \\
1 / 2 \text { to } 1 \text { oz/week }(n=119), 1 \text { or more oz/week } \\
(n=119)\end{array}$ & 790 & NR \\
\hline Cervigni, $2019^{62}$ & longitudinal ${ }^{\dagger}$ & Italy & $\begin{array}{l}\text { interstitial cystitis/bladder } \\
\text { pain syndrome }\end{array}$ & PEA & $\begin{array}{l}400 \mathrm{mg} \text { m-PEA plus } 40 \mathrm{mg} \text { polydatin bid for } 3 \\
\text { months, od for } 3 \text { months }\end{array}$ & 32 & 24 \\
\hline \multirow[t]{3}{*}{$\operatorname{Cremer-Schaeffer,~}_{63} 2019$} & longitudinal†† & Germany & $\begin{array}{l}\text { mixed cancer and non-cancer } \\
\text { pain }\end{array}$ & dronabinol & NR & 2017 & 52 \\
\hline & & & & mixed herbal & NR & 656 & \\
\hline & & & & nabiximols & NR & 393 & \\
\hline Lejczak, $2019^{64}$ & longitudinal ${ }^{\dagger}$ & France & $\begin{array}{l}\text { mixed cancer and non-cancer } \\
\text { pain }\end{array}$ & dronabinol & range: 2.5 to $30 \mathrm{mg} / \mathrm{day}$ & 148 & range: 4 to 24 weeks \\
\hline Loi, $2019^{65}$ & longitudinal* & Italy & endometriosis & PEA & $\begin{array}{c}600 \mathrm{mg} / \mathrm{bid} \text { for } 10 \text { days; } 400 \mathrm{mg} \text { m-PEA plus } 40 \\
\text { mg polydatin bid }\end{array}$ & 28 & 12.9 \\
\hline Naftali, $2019^{66}$ & longitudinal* & Israel & inflammatory bowel disease & mixed herbal & mean: $31 \mathrm{~g} /$ month & 127 & median: 176 \\
\hline
\end{tabular}




\begin{tabular}{|c|c|c|c|c|c|c|c|c|}
\hline & & & & & mean: $21 \mathrm{~g} /$ day THC; $170 \mathrm{~g} /$ day CBD & & & 츰. \\
\hline Perron, $2019^{67}$ & cross-sectional* & US & mixed non-cancer pain & $\mathrm{NR}$ & daily $(n=580)$, weekly $(n=85)$ & 618 & $\geq 12$ & $\sum$ 흥 \\
\hline Sagy, $2019^{68}$ & longitudinalt† & Israel & $\begin{array}{l}\text { mixed cancer and non-cancer } \\
\text { pain }\end{array}$ & mixed herbal & $\begin{array}{c}\text { median: } 1000 \mathrm{mg} / \text { day cannabis } \\
\text { median: } 140 \mathrm{mg} / \text { day THC; } 39 \mathrm{mg} / \text { day CBD }\end{array}$ & 239 & 24 & 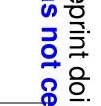 \\
\hline Sinclair, $2019^{69}$ & cross-sectional* & Australia & endometriosis & mixed herbal & $\begin{array}{l}\text { less than once per week (n=12), once per } \\
\text { week }(n=6) \text {, two to six times per week }(n=9) \text {, } \\
\text { daily or multiple times per day }(n=21)\end{array}$ & 48 & NR & 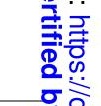 \\
\hline Ueberall, $2019^{70}$ & 列 & Germany & $\begin{array}{c}\text { low back pain }(n=234) \text {, failed } \\
\text { back surgery syndrome } \\
\text { ( } n=148), \text { shoulder/neck pain } \\
(n=91), \text { post-herpetic } \\
\text { neuralgia ( } n=72) \text {, peripheral } \\
\text { diabetic neuropathy }(n=56), \\
\text { brachial plexus injury }(n=48), \\
\text { lumbar spinal stenosis ( } n=38) \text {, } \\
\text { cancer }(n=31), \text { fibromyalgia } \\
\text { ( } n=26), \text { peripheral/focal } \\
\text { nerve lesions }(n=22), \\
\text { phantom pain }(n=19), \\
\text { osteoarthritis }(n=15)\end{array}$ & nabiximols & mean: 7.1 sprays/day & 800 & 12 & 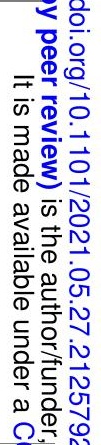 \\
\hline Vigil, $2017^{71}$ & longitudinal* & US & mixed non-cancer pain & NR & NR & 37 & mean: 82.4 & wenc. \\
\hline Yassin, $2019^{72}$ & longitudinalt† & Israel & fibromyalgia & mixed herbal & 20 to $30 \mathrm{~g} / \mathrm{month}$ & 31 & 24 & 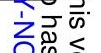 \\
\hline Giorgi, $2020^{73}$ & longitudinal†† & Italy & fibromyalgia & extracts & $\begin{array}{c}10 \text { to } 30 \text { drops/day; no more than } 120 \\
\text { drops/day }\end{array}$ & 102 & 24 & \\
\hline $\begin{array}{l}\text { NR=not reported } \\
\text { *Patient-report } \\
\text { tClinician-report } \\
\text { +tNR }\end{array}$ & & & & & & & & 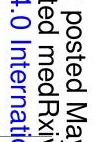 \\
\hline $\begin{array}{l}513 \\
514\end{array}$ & & & & & & & & 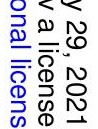 \\
\hline 515 & & & & & & & & 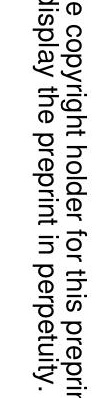 \\
\hline
\end{tabular}


medRxiv preprint doi: https://doi.org/10.1101/2021.05.27.21257921; this version posted May 29, 2021. The copyright holder for this preprint (which was not certified by peer review) is the author/funder, who has granted medRxiv a license to display the preprint in perpetuity.

It is made available under a CC-BY-NC-ND 4.0 International license.

Table 2: Prevalence of adverse events from non-comparative studies

\begin{tabular}{|c|c|c|c|c|c|c|c|}
\hline Outcome & $\begin{array}{c}\text { Numbe } \\
\text { r of } \\
\text { studies }\end{array}$ & $\begin{array}{c}\text { Number of } \\
\text { participant } \\
\text { s }\end{array}$ & $\begin{array}{c}\text { Duratio } \\
\text { n of } \\
\text { follow- } \\
\text { up } \\
\text { (weeks) }\end{array}$ & $\begin{array}{c}\text { Prevalenc } \\
\text { e \% (95\% } \\
\text { CI) }\end{array}$ & $\begin{array}{c}1^{2} \\
(\% \\
1 \%\end{array}$ & $\begin{array}{c}\text { Certaint } \\
\mathbf{y}\end{array}$ & Reasons for downgrading \\
\hline $\begin{array}{l}\text { All adverse } \\
\text { events }\end{array}$ & 22 & 4,108 & 4 to 94 & \multicolumn{2}{|c|}{$\begin{array}{l}\text { The prevalence of } \\
\text { adverse events } \\
\text { ranged between } 0 \% \\
\text { to } 92.1 \% \text {. Studies with } \\
\text { less than } 24 \text { weeks of } \\
\text { cannabis use typically } \\
\text { reported fewer } \\
\text { adverse events than } \\
\text { those with more than } \\
24 \text { weeks. Patients } \\
\text { using PEA } \\
\text { experienced no } \\
\text { adverse events. The } \\
\text { evidence was overall } \\
\text { very uncertain due to } \\
\text { risk of bias and } \\
\text { inconsistency. }\end{array}$} & very low & risk of bias (3 levels), inconsistency \\
\hline
\end{tabular}

Adverse

events causing discontinuatio

n
20

6,509
4 to 66
The prevalence of discontinuations due to adverse events ranged between $0 \%$ to $27.0 \%$. Studies with less than 24 weeks of cannabis use typically

reported fewer discontinuations than those with more than

24 weeks. Patients using PEA experienced no adverse events. The evidence was overall very uncertain due to

risk of bias and

inconsistency. very low risk of bias (3 levels), inconsistency

\begin{tabular}{|c|c|c|c|c|c|c|c|}
\hline $\begin{array}{l}\text { Serious } \\
\text { adverse } \\
\text { events }\end{array}$ & 24 & 4,273 & 4 to 94 & $1.2(0.1$ to 3.1$)$ & 91 & very low & risk of bias (3 levels) \\
\hline \multicolumn{8}{|c|}{ Psychiatric adverse events } \\
\hline $\begin{array}{l}\text { Psychiatric } \\
\text { disorder }\end{array}$ & 4 & 1,458 & 12 to 66 & $\begin{array}{l}13.5(2.6 \text { to } \\
30.6)\end{array}$ & 98 & very low & $\begin{array}{l}\text { risk of bias ( } 3 \text { levels), inconsistency, } \\
\text { imprecision }\end{array}$ \\
\hline Suicide & 1 & 215 & 52 & $0(0$ to 0.8$)$ & NA & very low & risk of bias (3 levels) \\
\hline $\begin{array}{l}\text { Suicidal } \\
\text { thoughts }\end{array}$ & 1 & 3,066 & 52 & 0.1 (0 to 0.5$)$ & 44 & very low & risk of bias (3 levels) \\
\hline Depression & 6 & 4,144 & 12 to 66 & 1.7 (0.9 to 2.7$)$ & 71 & very low & risk of bias (3 levels) \\
\hline Mania & 1 & 215 & 52 & $0.5(0$ to 2$)$ & NA & very low & risk of bias (3 levels) \\
\hline Hallucinations & 6 & 3,583 & 24 to 66 & $0.5(0.1$ to 1.3$)$ & 69 & very low & risk of bias (3 levels) \\
\hline Delusions & 4 & 3,281 & 52 & $0.4(0.2$ to 0.6$)$ & 0 & very low & risk of bias (3 levels) \\
\hline Paranoia & 3 & 277 & $\begin{array}{l}52 \text { to } 94 ; \\
\text { one cross- } \\
\text { sectional } \\
\text { study }\end{array}$ & $5.6(0$ to 19.2$)$ & 85 & very low & $\begin{array}{l}\text { risk of bias ( } 3 \text { levels), inconsistency, } \\
\text { imprecision }\end{array}$ \\
\hline
\end{tabular}


medRxiv preprint doi: https://doi.org/10.1101/2021.05.27.21257921; this version posted May 29, 2021. The copyright holder for this preprint (which was not certified by peer review) is the author/funder, who has granted medRxiv a license to display the preprint in perpetuity.

It is made available under a CC-BY-NC-ND 4.0 International license.

\begin{tabular}{|c|c|c|c|c|c|c|c|}
\hline Anxiety & 5 & 1,695 & $\begin{array}{l}12 \text { to } 94 ; \\
\text { two cross- } \\
\text { sectional } \\
\text { studies }\end{array}$ & $7.4(0$ to 26.9$)$ & 99 & very low & risk of bias (3 levels), imprecision \\
\hline Euphoria & 7 & 4,501 & 4 to 66 & $2.1(0.9$ to 3.8$)$ & 96 & very low & risk of bias (3 levels) \\
\hline \multicolumn{8}{|c|}{ Cognitive adverse events } \\
\hline $\begin{array}{l}\text { Memory } \\
\text { impairment }\end{array}$ & 6 & 4,484 & 4 to 176 & $5.3(2.1$ to 9.6$)$ & 96 & very low & risk of bias (3 levels) \\
\hline Confusion & 7 & 1,654 & 4 to 176 & $1.8(0.3$ to 4.2$)$ & 81 & very low & risk of bias (3 levels) \\
\hline Disorientation & 6 & 4,485 & 12 to 52 & $1.6(0.6$ to 3.0$)$ & 88 & very low & risk of bias (3 levels) \\
\hline $\begin{array}{l}\text { Attention } \\
\text { disorder or } \\
\text { deficit }\end{array}$ & 8 & 5,477 & 12 to 82 & $3.4(1.3$ to 6.3$)$ & 95 & very low & risk of bias (3 levels) \\
\hline \multicolumn{8}{|c|}{ Accidents and injuries } \\
\hline Falls & 1 & 215 & 52 & $2.3(0.7$ to 4.9$)$ & NA & very low & risk of bias (3 levels) \\
\hline $\begin{array}{l}\text { Motor vehicle } \\
\text { accidents }\end{array}$ & 1 & 215 & 52 & $0.5(0$ to 2.0$)$ & NA & very low & risk of bias (3 levels) \\
\hline \multicolumn{8}{|c|}{ Dependence and withdrawal } \\
\hline Dependence & 3 & 1,824 & $\begin{array}{l}\text { 12; one } \\
\text { cross- } \\
\text { sectional } \\
\text { study }\end{array}$ & $\begin{array}{l}4.4(0.0 \text { to } \\
19.9)\end{array}$ & 99 & very low & $\begin{array}{l}\text { risk of bias ( } 3 \text { levels), inconsistency, } \\
\text { imprecision, indirectness }\end{array}$ \\
\hline $\begin{array}{l}\text { Withdrawal } \\
\text { syndrome }\end{array}$ & 2 & 424 & 32 to 52 & $2.1(0$ to 8.2$)$ & 89 & very low & risk of bias (3 levels), indirectness \\
\hline $\begin{array}{l}\text { Withdrawal } \\
\text { symptoms }\end{array}$ & 1 & 618 & $\begin{array}{l}\text { NA; cross- } \\
\text { sectional }\end{array}$ & $\begin{array}{c}67.8(64.1 \text { to } \\
71.4)\end{array}$ & NA & very low & risk of bias (3 levels), indirectness \\
\hline
\end{tabular}


Table 3: Risk differences for adverse events from comparative studies

\begin{tabular}{|c|c|c|c|c|c|c|c|c|c|c|}
\hline Outcome & Exposure & $\begin{array}{c}\text { Number } \\
\text { of } \\
\text { studies }\end{array}$ & $\begin{array}{l}\text { Number of } \\
\text { participants }\end{array}$ & $\begin{array}{c}\text { Follow- } \\
\text { up } \\
\text { (weeks) }\end{array}$ & $\begin{array}{c}\text { Risk } \\
\text { with } \\
\text { cannabis } \\
(/ 1000)\end{array}$ & $\begin{array}{c}\text { Risk with } \\
\text { comparator } \\
(/ 1000)\end{array}$ & Risk difference $(95 \% \mathrm{CI})$ & Certainty & Reasons for downgrading & 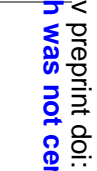 \\
\hline $\begin{array}{l}\text { All adverse } \\
\text { events }\end{array}$ & $\begin{array}{l}\text { Nabilone vs. } \\
\text { gabapentin }\end{array}$ & 1 & 220 & 24 & 404 & 534 & $-13.1 \%$ (-26.2 to 0$)$ & Very low & Risk of bias (2 levels), imprecision & 害蛋 \\
\hline \multirow[t]{2}{*}{$\begin{array}{l}\text { Adverse events } \\
\text { causing } \\
\text { discontinuation }\end{array}$} & $\begin{array}{c}\text { Herbal } \\
\text { cannabis vs. } \\
\text { standard care }\end{array}$ & 1 & 431 & 52 & 47 & 0 & $4.7 \%$ (1.8 to 7.5$)$ & Low & Risk of bias (2 levels), & 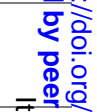 \\
\hline & $\begin{array}{l}\text { Nabilone vs. } \\
\text { gabapentin }\end{array}$ & 1 & 220 & 24 & 96 & 190 & $-9.4 \%(-18.5$ to -0.2$)$ & Very low & Risk of bias (2 levels), imprecision & 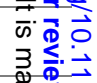 \\
\hline \multirow[t]{2}{*}{ Serious } & $\begin{array}{c}\text { Herbal } \\
\text { cannabis vs. } \\
\text { standard care }\end{array}$ & 1 & 431 & 52 & 130 & 194 & $1.5 \%(-8.3$ to 20.2$) *$ & Low & Risk of bias, imprecision & 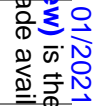 \\
\hline & $\begin{array}{l}\text { Nabilone vs. } \\
\text { gabapentin }\end{array}$ & 1 & 220 & 24 & 0 & 0 & $0 \%(0$ to 0$)$ & Very low & Risk of bias (2 levels), imprecision & \\
\hline $\begin{array}{l}\text { Psychiatric } \\
\text { disorder }\end{array}$ & $\begin{array}{c}\text { Herbal } \\
\text { cannabis vs. } \\
\text { standard care }\end{array}$ & 1 & 431 & 52 & 219 & 97 & $16.9 \%(5.8$ to 40.5$)+$ & Very low & Risk of bias (2 levels), imprecision & 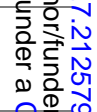 \\
\hline Suicide & $\begin{array}{c}\text { Herbal } \\
\text { cannabis vs. } \\
\text { standard care }\end{array}$ & 1 & 431 & 52 & 0 & 5 & $-0.5 \%(-1.4$ to 0.4$)$ & Low & Risk of bias (2 levels) & 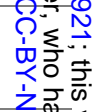 \\
\hline Mania & $\begin{array}{c}\text { Herbal } \\
\text { cannabis vs. } \\
\text { standard care }\end{array}$ & 1 & 431 & 52 & 5 & 0 & $0.5 \%(-0.4$ to 1.4$)$ & Low & Risk of bias (2 levels) & 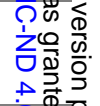 \\
\hline Hallucinations & $\begin{array}{c}\text { Herbal } \\
\text { cannabis vs. } \\
\text { standard care }\end{array}$ & 1 & 431 & 52 & 5 & 0 & $0.5 \%(-0.4$ to 1.4$)$ & Low & Risk of bias (2 levels) & 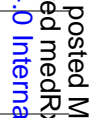 \\
\hline Delusions & $\begin{array}{c}\text { Herbal } \\
\text { cannabis vs. } \\
\text { standard care }\end{array}$ & 1 & 431 & 52 & 0 & 5 & $-0.5 \%(-1.4$ to 0.4$)$ & Low & Risk of bias (2 levels) & 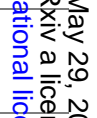 \\
\hline Depression & $\begin{array}{c}\text { Herbal } \\
\text { cannabis vs. } \\
\text { standard care }\end{array}$ & 1 & 431 & 52 & 47 & 46 & $0.1 \%$ (-4 to 4$)$ & Low & Risk of bias ( 2 levels) & 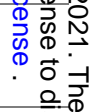 \\
\hline Paranoia & $\begin{array}{c}\text { Herbal } \\
\text { cannabis vs. } \\
\text { standard care }\end{array}$ & 1 & 431 & 52 & 9 & 0 & $0.9 \%(-0.4$ to 2.2$)$ & Low & Risk of bias (2 levels) & 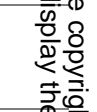 \\
\hline Anxiety & $\begin{array}{c}\text { Herbal } \\
\text { cannabis vs. } \\
\text { standard care }\end{array}$ & 1 & 431 & 52 & 47 & 9 & $3.8 \%(0.6$ to 6.8$)$ & Low & Risk of bias (2 levels) & 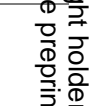 \\
\hline Euphoria & $\begin{array}{c}\text { Herbal } \\
\text { cannabis vs. } \\
\text { standard care }\end{array}$ & 1 & 431 & 52 & 42 & 0 & $4.2 \%$ (1.5 to 6.9$)$ & Low & Risk of bias ( 2 levels) & 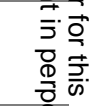 \\
\hline
\end{tabular}




\begin{tabular}{|c|c|c|c|c|c|c|c|c|c|}
\hline $\begin{array}{l}\text { Memory } \\
\text { impairment }\end{array}$ & $\begin{array}{c}\text { Herbal } \\
\text { cannabis vs. } \\
\text { standard care }\end{array}$ & 1 & 431 & 52 & 19 & 0 & $1.9 \%$ (0.1 to 3.7$)$ & Low & Risk of bias (2 levels) \\
\hline Confusion & $\begin{array}{c}\text { Herbal } \\
\text { cannabis vs. } \\
\text { standard care }\end{array}$ & 1 & 431 & 52 & 14 & 19 & $-0.5 \%(-2.8$ to 1.9$)$ & Low & Risk of bias (2 levels) \\
\hline $\begin{array}{l}\text { Disturbance in } \\
\text { attention }\end{array}$ & $\begin{array}{c}\text { Herbal } \\
\text { cannabis vs. } \\
\text { standard care }\end{array}$ & 1 & 431 & 52 & 23 & 9 & $1.4 \%(-1$ to 3.8$)$ & Low & Risk of bias (2 levels) \\
\hline Falls & $\begin{array}{c}\text { Herbal } \\
\text { cannabis vs. } \\
\text { standard care }\end{array}$ & 1 & 431 & 52 & 23 & 23 & $0 \%(-2.8$ to 2.9$)$ & Low & Risk of bias (2 levels) \\
\hline $\begin{array}{l}\text { Motor vehicle } \\
\text { accidents }\end{array}$ & $\begin{array}{c}\text { Herbal } \\
\text { cannabis vs. } \\
\text { standard care }\end{array}$ & 1 & 431 & 52 & 5 & 0 & $0.5 \%(-0.4$ to 1.4$)$ & Low & Risk of bias (2 levels) \\
\hline $\begin{array}{l}\text { Withdrawal } \\
\text { syndrome }\end{array}$ & $\begin{array}{c}\text { Herbal } \\
\text { cannabis vs. } \\
\text { standard care }\end{array}$ & 1 & 431 & 52 & 5 & 0 & $0.5 \%(-0.4$ to 1.4$)$ & Very low & Risk of bias (2 levels), \\
\hline
\end{tabular}




\section{Figures}

\section{$517 \quad$ Figure 1: Study selection process}

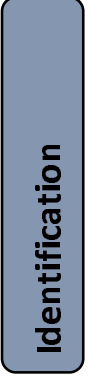

\section{Records identified through} database searching

$$
\text { ( } n=23,260)
$$

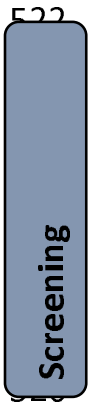

Records after duplicates removed

$(n=17,178)$
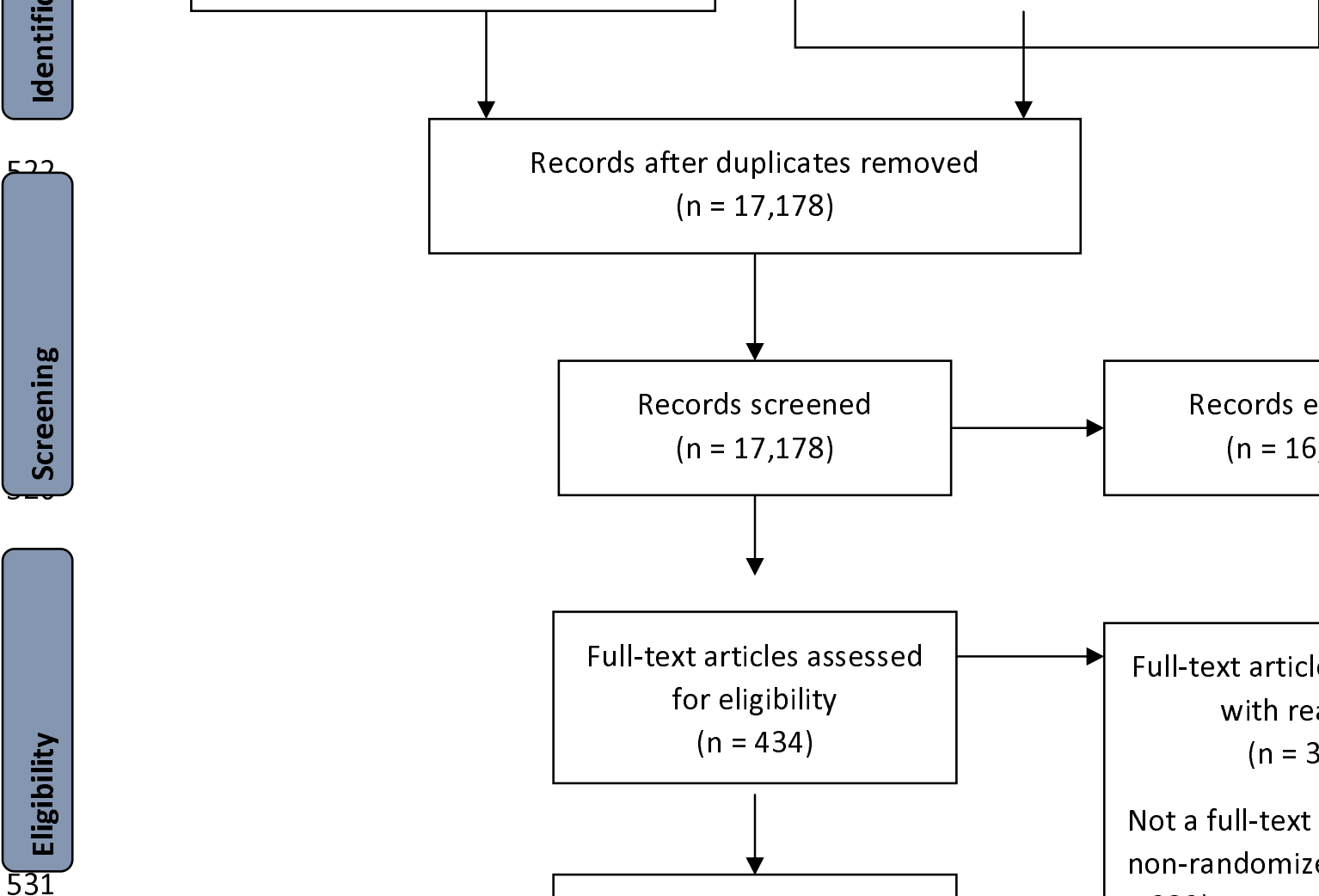
through other sources
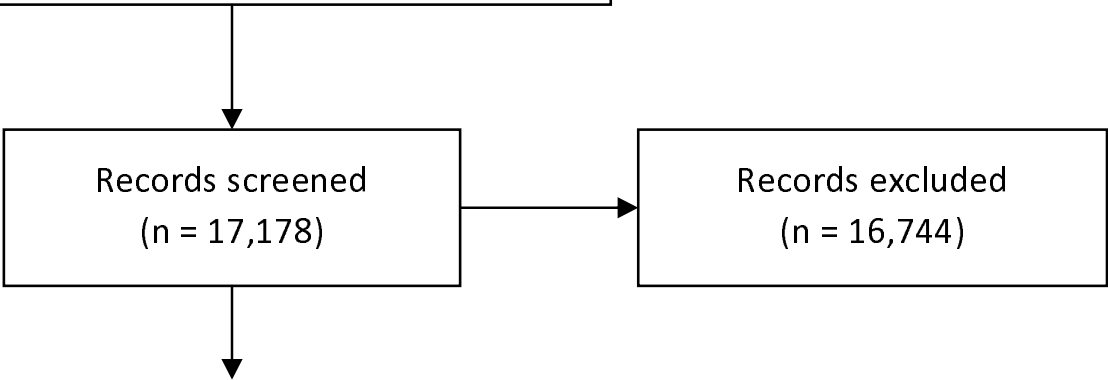

Full-text articles assessed for eligibility ( $n=434)$

Studies included in qualitative synthesis

$$
(n=39)
$$

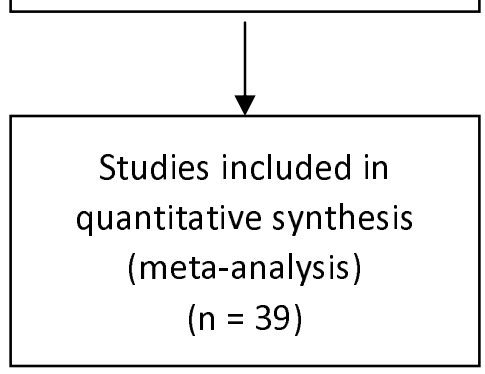

537
Full-text articles excluded, with reasons

$$
(n=395)
$$

Not a full-text report of a non-randomized study ( $\mathrm{n}$ = 239)

Study did not include patients with chronic pain $(n=86)$

Study did not report on medical cannabis $(n=25)$

Study did not report on harms or adverse events ( $n=42$ )

Study included fewer than 25 patients $(n=3)$ 
medRxiv preprint doi: https://doi.org/10.1101/2021.05.27.21257921; this version posted May 29, 2021. The copyright holder for this preprint (which was not certified by peer review) is the author/funder, who has granted medRxiv a license to display the preprint in perpetuity.

It is made available under a CC-BY-NC-ND 4.0 International license .

Figure 2: Forest plot of the meta-analysis for all adverse events stratified by type of medical cannabis

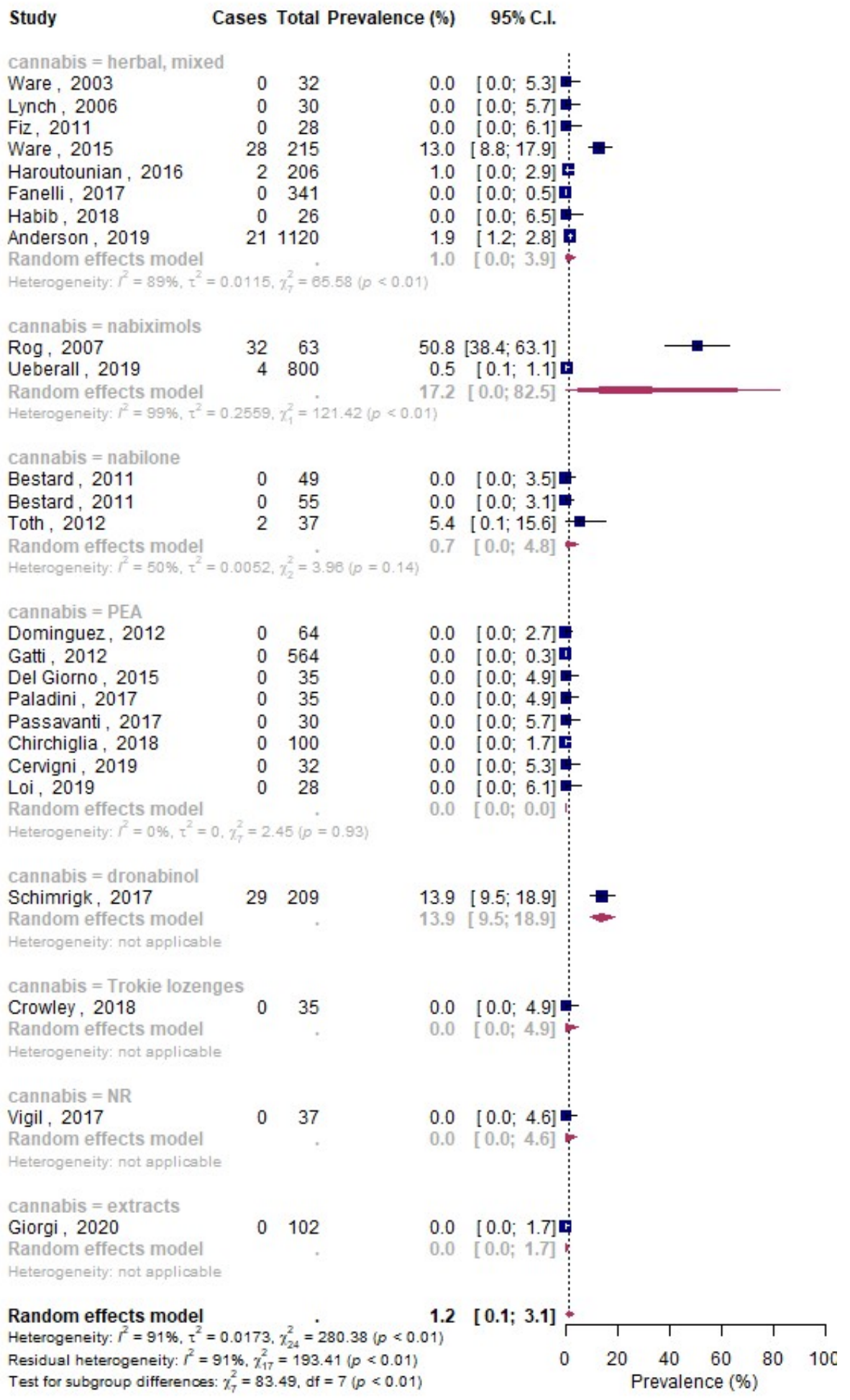

542

543 
medRxiv preprint doi: https://doi.org/10.1101/2021.05.27.21257921; this version posted May 29, 2021. The copyright holder for this preprint (which was not certified by peer review) is the author/funder, who has granted medRxiv a license to display the preprint in perpetuity.

It is made available under a CC-BY-NC-ND 4.0 International license .

\section{References}

1. Mills SEE, Nicolson KP, Smith BH. Chronic pain: a review of its epidemiology and associated factors in population-based studies. Br J Anaesth 2019;123(2):e273-e83. doi: 10.1016/j.bja.2019.03.023 [published Online First: 2019/05/14]

2. Mills SEE, van Hecke O, Smith BH. Handbook of Pain and Palliative Care: Biopsychosocial and Environmental Approaches for the Life Course. 2019.

3. Keyhani S, Steigerwald S, Ishida J, et al. Risks and Benefits of Marijuana Use: A National Survey of U.S. Adults. Ann Intern Med 2018;169(5):282-90. doi: 10.7326/m18-0810 [published Online First: 2018/07/25]

4. Dai H, Richter KP. A National Survey of Marijuana Use Among US Adults With Medical Conditions, 2016-2017. JAMA Netw Open 2019;2(9):e1911936. doi: 10.1001/jamanetworkopen.2019.11936 [published Online First: 2019/09/21]

5. National Academies of Sciences E, Medicine, Health, et al. The National Academies Collection: Reports funded by National Institutes of Health. The Health Effects of Cannabis and Cannabinoids: The Current State of Evidence and Recommendations for Research. Washington (DC): National Academies Press (US)

Copyright 2017 by the National Academy of Sciences. All rights reserved. 2017.

6. Carr D, Schatman M. Cannabis for Chronic Pain: Not Ready for Prime Time. American Journal of Public Health 2019;109(1):50-51. doi: 10.2105/AJPH.2018.304593 [published Online First: 2019/01/]

7. Ziemianski D, Capler R, Tekanoff R, et al. Cannabis in medicine: a national educational needs assessment among Canadian physicians. BMC Med Educ 2015;15:52. doi: 10.1186/s12909-0150335-0 [published Online First: 2015/04/19]

8. Kahan M, Srivastava A. Is there a role for marijuana in medical practice? No. Can Fam Physician 2007;53(1):22-5. [published Online First: 2007/09/18]

9. Ware MA. Is there a role for marijuana in medical practice? Yes. Can Fam Physician 2007;53(1):22-5. [published Online First: 2007/09/18]

10. Deshpande A, Mailis-Gagnon A, Zoheiry N, et al. Efficacy and adverse effects of medical marijuana for chronic noncancer pain: Systematic review of randomized controlled trials. Can Fam Physician 2015;61(8):e372-81. [published Online First: 2015/10/28]

11. Wang L, Hong $P$, May $C$, et al. Medical cannabis for chronic pain: a systematic review and metaanalysis of randomized clinical trials. BMJ 2020;Submitted

12. Wang T, Collet JP, Shapiro S, et al. Adverse effects of medical cannabinoids: a systematic review. Cmaj 2008;178(13):1669-78. doi: 10.1503/cmaj.071178 [published Online First: 2008/06/19]

13. Whiting PF, Wolff RF, Deshpande S, et al. Cannabinoids for Medical Use: A Systematic Review and Meta-analysis. Jama 2015;313(24):2456-73. doi: 10.1001/jama.2015.6358 [published Online First: 2015/06/24]

14. Hill KP, Hurley-Welljams-Dorof WM. Low to moderate quality evidence demonstrates the potential benefits and adverse events of cannabinoids for certain medical indications. Evid Based Med 2016;21(1):17. doi: 10.1136/ebmed-2015-110264 [published Online First: 2015/10/23]

15. Bair MJ, Robinson RL, Katon W, et al. Depression and pain comorbidity: a literature review. Arch Intern Med 2003;163(20):2433-45. doi: 10.1001/archinte.163.20.2433 [published Online First: 2003/11/12]

16. Magni G, Marchetti M, Moreschi C, et al. Chronic musculoskeletal pain and depressive symptoms in the National Health and Nutrition Examination. I. Epidemiologic follow-up study. Pain 1993;53(2):163-8. doi: 10.1016/0304-3959(93)90076-2 [published Online First: 1993/05/01] 
medRxiv preprint doi: https://doi.org/10.1101/2021.05.27.21257921; this version posted May 29, 2021. The copyright holder for this preprint (which was not certified by peer review) is the author/funder, who has granted medRxiv a license to display the preprint in perpetuity.

It is made available under a CC-BY-NC-ND 4.0 International license .

17. Wilson KG, Eriksson MY, D'Eon JL, et al. Major depression and insomnia in chronic pain. Clin J Pain 2002;18(2):77-83. doi: 10.1097/00002508-200203000-00002 [published Online First: 2002/03/08]

18. Siemieniuk RA, Agoritsas T, Macdonald H, et al. Introduction to BMJ Rapid Recommendations. Bmj 2016;354:i5191. doi: 10.1136/bmj.i5191 [published Online First: 2016/09/30]

19. Zeng L, Lytvyn L, Wang $X$, et al. Values and preferences towards medical cannabis among patients with chronic pain: A mixed methods systematic review. BMJ 2020;Submitted

20. Noori A, Miroshnychenko A, Shergill Y, et al. Opioid-Sparing effects of medical cannabis for chronic pain: A systematic review and meta-analysis of randomized and observational studies. BMJ 2020;Submitted

21. Busse J, Vankrunkelsven P, Zeng L, et al. Medical cannabis for chronic pain: a clinical practice guideline. BMJ 2020;Submitted.

22. Zorzela L, Loke YK, loannidis JP, et al. PRISMA harms checklist: improving harms reporting in systematic reviews. Bmj 2016;352:i157. doi: 10.1136/bmj.i157 [published Online First: 2016/02/03]

23. Busse JW, Bartlett SJ, Dougados M, et al. Optimal Strategies for Reporting Pain in Clinical Trials and Systematic Reviews: Recommendations from an OMERACT 12 Workshop. J Rheumatol 2015;42(10):1962-70. doi: 10.3899/jrheum.141440 [published Online First: 2015/05/17]

24. Sterne JA, Hernán MA, Reeves BC, et al. ROBINS-I: a tool for assessing risk of bias in non-randomised studies of interventions. Bmj 2016;355:i4919. doi: 10.1136/bmj.i4919 [published Online First: 2016/10/14]

25. Freeman MF, Tukey JW. Transformations related to the angular and the square root. The Annals of Mathematical Statistics 1950:607-11.

26. DerSimonian R, Laird N. Meta-analysis in clinical trials. Controlled clinical trials 1986;7(3):177-88.

27. Murad M, Montori $V$, Ioannidis J, et al. Fixed-effects and random-effects models. Users' guide to the medical literature A manual for evidence-based clinical practice McGraw-Hill, 3rd ed New York, America 2015

28. Rücker G, Schwarzer G, Carpenter JR, et al. Undue reliance on I(2) in assessing heterogeneity may mislead. BMC Med Res Methodol 2008;8:79. doi: 10.1186/1471-2288-8-79 [published Online First: 2008/11/28]

29. Sun X, Briel M, Walter SD, et al. Is a subgroup effect believable? Updating criteria to evaluate the credibility of subgroup analyses. Bmj 2010;340:c117. doi: 10.1136/bmj.c117 [published Online First: 2010/04/01]

30. Schandelmaier S, Briel M, Varadhan R, et al. Development of the Instrument to assess the Credibility of Effect Modification Analyses (ICEMAN) in randomized controlled trials and meta-analyses. Cmaj 2020;192(32):E901-e06. doi: 10.1503/cmaj.200077 [published Online First: 2020/08/12]

31. Schwarzer G. meta: An R package for meta-analysis. R news 2007;7(3):40-45.

32. Schünemann HJ, Cuello C, AkI EA, et al. GRADE guidelines: 18. How ROBINS-I and other tools to assess risk of bias in nonrandomized studies should be used to rate the certainty of a body of evidence. J Clin Epidemiol 2019;111:105-14. doi: 10.1016/j.jclinepi.2018.01.012 [published Online First: 2018/02/13]

33. Guyatt GH, Oxman AD, Vist GE, et al. GRADE: an emerging consensus on rating quality of evidence and strength of recommendations. Bmj 2008;336(7650):924-6. doi: 10.1136/bmj.39489.470347.AD [published Online First: 2008/04/26]

34. Santesso N, Glenton C, Dahm P, et al. GRADE guidelines 26: informative statements to communicate the findings of systematic reviews of interventions. J Clin Epidemiol 2020;119:126-35. doi: 10.1016/j.jclinepi.2019.10.014 [published Online First: 2019/11/13] 
medRxiv preprint doi: https://doi.org/10.1101/2021.05.27.21257921; this version posted May 29, 2021. The copyright holder for this preprint (which was not certified by peer review) is the author/funder, who has granted medRxiv a license to display the preprint in perpetuity.

It is made available under a CC-BY-NC-ND 4.0 International license .

35. Ware MA, Doyle CR, Woods R, et al. Cannabis use for chronic non-cancer pain: results of a prospective survey. Pain 2003;102(1-2):211-6.

36. Lynch ME, Young J, Clark AJ. A case series of patients using medicinal marihuana for management of chronic pain under the Canadian Marihuana Medical Access Regulations. Journal of Pain \& Symptom Management 2006;32(5):497-501.

37. Rog DJ, Nurmikko TJ, Young CA. Oromucosal delta9-tetrahydrocannabinol/cannabidiol for neuropathic pain associated with multiple sclerosis: an uncontrolled, open-label, 2-year extension trial. Clinical Therapeutics 2007;29(9):2068-79.

38. Weber J, Schley M, Casutt M, et al. Tetrahydrocannabinol (Delta 9-THC) treatment in chronic central neuropathic pain and fibromyalgia patients: Results of a multicenter survey. Anesthesiology Research and Practice 2009;2009 (no pagination)(827290) doi: http://dx.doi.org/10.1155/2009/827290

39. Bestard JA, Toth CC. An open-label comparison of nabilone and gabapentin as adjuvant therapy or monotherapy in the management of neuropathic pain in patients with peripheral neuropathy. Pain Practice 2011;11(4):353-68. doi: https://dx.doi.org/10.1111/i.1533-2500.2010.00427.x

40. Fiz J, Duran M, Capella D, et al. Cannabis use in patients with Fibromyalgia: Effect on symptoms relief and health-related quality of life. PLOS ONE 2011;6 (4) (no pagination)(e18440) doi: http://dx.doi.org/10.1371/journal.pone.0018440

41. Domínguez CM, Martín AD, Ferrer FG, et al. N-palmitoylethanolamide in the treatment of neuropathic pain associated with lumbosciatica. Pain Manag 2012;2(2):119-24. doi: 10.2217/pmt.12.5 [published Online First: 2012/03/01]

42. Gatti A, Lazzari M, Gianfelice V, et al. Palmitoylethanolamide in the treatment of chronic pain caused by different etiopathogenesis. Pain Medicine 2012;13(9):1121-30. doi: https://dx.doi.org/10.1111/j.1526-4637.2012.01432.x

43. Toth C, Mawani S, Brady S, et al. An enriched-enrolment, randomized withdrawal, flexible-dose, double-blind, placebo-controlled, parallel assignment efficacy study of nabilone as adjuvant in the treatment of diabetic peripheral neuropathic pain. Pain 2012;153(10):2073-82. doi: http://dx.doi.org/10.1016/i.pain.2012.06.024

44. Schifilliti C, Cucinotta L, Fedele V, et al. Micronized palmitoylethanolamide reduces the symptoms of neuropathic pain in diabetic patients. Pain Res Treat 2014;2014:849623. doi: 10.1155/2014/849623 [published Online First: 2014/05/08]

45. Storr M, Devlin S, Kaplan GG, et al. Cannabis use provides symptom relief in patients with inflammatory bowel disease but is associated with worse disease prognosis in patients with Crohn's disease. Inflammatory Bowel Diseases 2014;20(3):472-80. doi: https://dx.doi.org/10.1097/01.MIB.0000440982.79036.d6

46. Del Giorno R, Skaper S, Paladini A, et al. Palmitoylethanolamide in Fibromyalgia: Results from Prospective and Retrospective Observational Studies. Pain and Therapy 2015;4(2):169-78. doi: http://dx.doi.org/10.1007/s40122-015-0038-6

47. Hoggart B, Ratcliffe $S$, Ehler $E$, et al. A multicentre, open-label, follow-on study to assess the longterm maintenance of effect, tolerance and safety of THC/CBD oromucosal spray in the management of neuropathic pain. Journal of Neurology 2015;262(1):27-40. doi: https://dx.doi.org/10.1007/s00415-014-7502-9

48. Ware MA, Wang T, Shapiro S, et al. Cannabis for the Management of Pain: Assessment of Safety Study (COMPASS). Journal of Pain 2015;16(12):1233-42. doi: https://dx.doi.org/10.1016/i.jpain.2015.07.014

49. Haroutounian S, Ratz Y, Ginosar Y, et al. The Effect of Medicinal Cannabis on Pain and Quality-of-Life Outcomes in Chronic Pain: A Prospective Open-label Study. Clinical Journal of Pain 2016;32(12):1036-43. 
medRxiv preprint doi: https://doi.org/10.1101/2021.05.27.21257921; this version posted May 29, 2021. The copyright holder for this preprint (which was not certified by peer review) is the author/funder, who has granted medRxiv a license to display the preprint in perpetuity.

It is made available under a CC-BY-NC-ND 4.0 International license .

50. Bellnier T, Brown G, Ortega T, et al. A preliminary evaluation of the effcacy, safety, and costs associated with the treatment of chronic pain with medical marijuana in the elderly. Consultant Pharmacist 2017;32 (10):597. doi: http://dx.doi.org/10.4140/TCPn.2017.577

51. Cranford JA, Arnedt JT, Conroy DA, et al. Prevalence and correlates of sleep-related problems in adults receiving medical cannabis for chronic pain. Drug \& Alcohol Dependence 2017;180:22733. doi: https://dx.doi.org/10.1016/i.drugalcdep.2017.08.017

52. Fanelli G, De Carolis G, Leonardi C, et al. Cannabis and intractable chronic pain: an explorative retrospective analysis of Italian cohort of 614 patients. Journal of pain research 2017;10:121724. doi: https://dx.doi.org/10.2147/JPR.S132814

53. Feingold D, Goor-Aryeh I, Bril S, et al. Problematic Use of Prescription Opioids and Medicinal Cannabis Among Patients Suffering from Chronic Pain. Pain Medicine 2017;18(2):294-306. doi: https://dx.doi.org/10.1093/pm/pnw134

54. Paladini A, Varrassi G, Bentivegna G, et al. Palmitoylethanolamide in the Treatment of Failed Back Surgery Syndrome. Pain Res Treat 2017;2017:1486010. doi: 10.1155/2017/1486010 [published Online First: 2017/09/07]

55. Passavanti MB, Fiore $M$, Sansone $P$, et al. The beneficial use of ultramicronized palmitoylethanolamide as add-on therapy to Tapentadol in the treatment of low back pain: a pilot study comparing prospective and retrospective observational arms. BMC Anesthesiology 2017;17(1):171. doi: https://dx.doi.org/10.1186/s12871-017-0461-9

56. Schimrigk S, Marziniak M, Neubauer C, et al. Dronabinol Is a Safe Long-Term Treatment Option for Neuropathic Pain Patients. European Neurology 2017;78(5-6):320-29. doi: https://dx.doi.org/10.1159/000481089

57. Chirchiglia D, Chirchiglia P, Signorelli F. Nonsurgical lumbar radiculopathies treated with ultramicronized palmitoylethanolamide (UMPEA): A series of 100 cases. Neurologia $i$ Neurochirurgia Polska 2018;52(1):44-47. doi: https://dx.doi.org/10.1016/i.pinns.2017.11.002

58. Crowley K, de Vries ST, Moreno-Sanz G. Self-Reported Effectiveness and Safety of Trokie R Lozenges: A Standardized Formulation for the Buccal Delivery of Cannabis Extracts. Frontiers in Neuroscience 2018;12:564. doi: https://dx.doi.org/10.3389/fnins.2018.00564

59. Habib G, Artul S. Medical Cannabis for the Treatment of Fibromyalgia. JCR: Journal of Clinical Rheumatology 2018;24(5):255-58. doi: https://dx.doi.org/10.1097/RHU.0000000000000702

60. Anderson SP, Zylla DM, McGriff DM, et al. Impact of medical cannabis on patient-reported symptoms for patients with cancer enrolled in Minnesota's medical cannabis program. Journal of Oncology Practice 2019;15(6):E338-E45. doi: http://dx.doi.org/10.1200/JOP.18.00619

61. Bonar EE, Cranford JA, Arterberry BJ, et al. Driving under the influence of cannabis among medical cannabis patients with chronic pain. Drug \& Alcohol Dependence 2019;195:193-97. doi: https://dx.doi.org/10.1016/i.drugalcdep.2018.11.016

62. Cervigni M, Nasta L, Schievano C, et al. Micronized Palmitoylethanolamide-Polydatin Reduces the Painful Symptomatology in Patients with Interstitial Cystitis/Bladder Pain Syndrome. BioMed Research International 2019;2019 (no pagination)(9828397) doi: http://dx.doi.org/10.1155/2019/9828397

63. Cremer-Schaeffer P, Schmidt-Wolf G, Broich K. [Cannabis medicines in pain management : Interim analysis of the survey accompanying the prescription of cannabis-based medicines in Germany with regard to pain as primarily treated symptom]. Der Schmerz 2019;33(5):415-23. doi: https://dx.doi.org/10.1007/s00482-019-00399-z

64. Lejczak S, Rousselot H, Di Patrizio P, et al. Dronabinol use in France between 2004 and 2017. Revue Neurologique 2019;175(5):298-304. doi: https://dx.doi.org/10.1016/j.neurol.2018.07.011

65. Loi ES, Pontis A, Cofelice V, et al. Effect of ultramicronized-palmitoylethanolamide and comicronizedpalmitoylethanolamide/polydatin on chronic pelvic pain and quality of life in 
medRxiv preprint doi: https://doi.org/10.1101/2021.05.27.21257921; this version posted May 29, 2021. The copyright holder for this preprint (which was not certified by peer review) is the author/funder, who has granted medRxiv a license to display the preprint in perpetuity.

It is made available under a CC-BY-NC-ND 4.0 International license .

endometriosis patients: An open-label pilot study. International Journal of Women's Health 2019;11:443-49. doi: http://dx.doi.org/10.2147/IJWH.S204275

66. Naftali T, Bar-Lev Schleider L, Sklerovsky Benjaminov F, et al. Medical cannabis for inflammatory bowel disease: real-life experience of mode of consumption and assessment of side-effects. European Journal of Gastroenterology \& Hepatology 2019;31(11):1376-81. doi: https://dx.doi.org/10.1097/MEG.0000000000001565

67. Perron BE, Holt KR, Yeagley E, et al. Mental health functioning and severity of cannabis withdrawal among medical cannabis users with chronic pain. Drug \& Alcohol Dependence 2019;194:401-09. doi: https://dx.doi.org/10.1016/i.drugalcdep.2018.09.029

68. Sagy I, Bar-Lev Schleider L, Abu-Shakra M, et al. Safety and Efficacy of Medical Cannabis in Fibromyalgia. Journal of Clinical Medicine 2019;8(6):05. doi: https://dx.doi.org/10.3390/icm8060807

69. Sinclair J, Smith CA, Abbott J, et al. Cannabis Use, a Self-Management Strategy Among Australian Women With Endometriosis: Results From a National Online Survey. Journal of Obstetrics \& Gynaecology Canada: JOGC 2020;42(3):256-61. doi: https://dx.doi.org/10.1016/i.jogc.2019.08.033

70. Ueberall MA, Essner U, Mueller-Schwefe GHH. Effectiveness and tolerability of THC:CBD oromucosal spray as add-on measure in patients with severe chronic pain: Analysis of 12-week open-label real-world data provided by the German pain e-registry. Journal of Pain Research 2019;12:1577604. doi: http://dx.doi.org/10.2147/JPR.S192174

71. Vigil JM, Stith SS, Adams IM, et al. Associations between medical cannabis and prescription opioid use in chronic pain patients: A preliminary cohort study. PLOS ONE [Electronic Resource] 2017;12(11):e0187795. doi: https://dx.doi.org/10.1371/journal.pone.0187795

72. Yassin M, Oron A, Robinson D. Effect of adding medical cannabis to analgesic treatment in patients with low back pain related to fibromyalgia: an observational cross-over single centre study. Clinical \& Experimental Rheumatology 2019;37 Suppl 116(1):13-20.

73. Giorgi V, Bongiovanni S, Atzeni F, et al. Adding medical cannabis to standard analgesic treatment for fibromyalgia: a prospective observational study. Clinical \& Experimental Rheumatology 2020;38 Suppl 123(1):53-59.

74. Grant BF, Dawson DA, Stinson FS, et al. The Alcohol Use Disorder and Associated Disabilities Interview Schedule-IV (AUDADIS-IV): reliability of alcohol consumption, tobacco use, family history of depression and psychiatric diagnostic modules in a general population sample. Drug Alcohol Depend 2003;71(1):7-16. doi: 10.1016/s0376-8716(03)00070-x [published Online First: 2003/06/25]

75. Humeniuk R, Ali R. Validation of the Alcohol, Smoking and Substance Involvement Screening Test (ASSIST) and pilot brief intervention: a technical report of phase II findings of the WHO ASSIST Project. Validation of the alcohol, smoking and substance involvement screening test (ASSIST) and pilot brief intervention: a technical report of phase II findings of the WHO ASSIST Project2006.

76. Stockings E, Campbell G, Hall WD, et al. Cannabis and cannabinoids for the treatment of people with chronic noncancer pain conditions: a systematic review and meta-analysis of controlled and observational studies. Pain 2018;159(10):1932-54. doi: 10.1097/j.pain.0000000000001293 [published Online First: 2018/05/31]

77. Allan GM, Finley CR, Ton J, et al. Systematic review of systematic reviews for medical cannabinoids: Pain, nausea and vomiting, spasticity, and harms. Can Fam Physician 2018;64(2):e78-e94. [published Online First: 2018/02/17] 
medRxiv preprint doi: https://doi.org/10.1101/2021.05.27.21257921; this version posted May 29, 2021. The copyright holder for this preprint (which was not certified by peer review) is the author/funder, who has granted medRxiv a license to display the preprint in perpetuity. It is made available under a CC-BY-NC-ND 4.0 International license .

78. Campeny E, López-Pelayo H, Nutt D, et al. The blind men and the elephant: Systematic review of systematic reviews of cannabis use related health harms. Eur Neuropsychopharmacol 2020;33:135. doi: 10.1016/j.euroneuro.2020.02.003 [published Online First: 2020/03/14]

79. Memedovich KA, Dowsett LE, Spackman E, et al. The adverse health effects and harms related to marijuana use: an overview review. CMAJ Open 2018;6(3):E339-e46. doi: 10.9778/cmajo.20180023 [published Online First: 2018/08/18]

80. Nugent SM, Morasco BJ, O'Neil ME, et al. The Effects of Cannabis Among Adults With Chronic Pain and an Overview of General Harms: A Systematic Review. Ann Intern Med 2017;167(5):319-31. doi: 10.7326/m17-0155 [published Online First: 2017/08/15]

81. Els C, Jackson TD, Kunyk D, et al. Adverse events associated with medium- and long-term use of opioids for chronic non-cancer pain: an overview of Cochrane Reviews. Cochrane Database Syst Rev 2017;10(10):Cd012509. doi: 10.1002/14651858.CD012509.pub2 [published Online First: 2017/10/31]

82. Diagnostic and statistical manual of mental disorders : DSM-5. Arlington, VA: American Psychiatric Association 2013.

83. Goodman JE, McGrath PJ. The epidemiology of pain in children and adolescents: a review. Pain 1991;46(3):247-64. doi: 10.1016/0304-3959(91)90108-a [published Online First: 1991/09/01]

84. Myles H, Myles N, Large M. Cannabis use in first episode psychosis: Meta-analysis of prevalence, and the time course of initiation and continued use. Aust N Z J Psychiatry 2016;50(3):208-19. doi: 10.1177/0004867415599846 [published Online First: 2015/08/20]

85. Shanthanna H, Gilron I, Rajarathinam M, et al. Benefits and safety of gabapentinoids in chronic low back pain: A systematic review and meta-analysis of randomized controlled trials. PLoS Med 2017;14(8):e1002369. doi: 10.1371/journal.pmed.1002369 [published Online First: 2017/08/16]

86. Ferraro MC, Bagg MK, Wewege MA, et al. Efficacy, acceptability, and safety of antidepressants for low back pain: a systematic review and meta-analysis. Syst Rev 2021;10(1):62. doi: 10.1186/s13643-021-01599-4 [published Online First: 2021/02/26]

87. Busse JW, Craigie S, Juurlink DN, et al. Guideline for opioid therapy and chronic noncancer pain. Cmaj 2017;189(18):E659-e66. doi: 10.1503/cmaj.170363 [published Online First: 2017/05/10] 